\title{
Using otolith microchemistry to assess nursery habitat contribution and function at a fine spatial scale
}

\author{
Janet A. Ley* , Holly J. Rolls \\ Fish and Wildlife Research Institute, Florida Fish and Wildlife Conservation Commission, 100 Eighth Avenue Southeast, \\ St. Petersburg, Florida 33701, USA
}

\begin{abstract}
Estuarine tributaries are vital links in connectivity for transient coastal fish undergoing ontogenetic habitat shifts, yet these resources are on the frontlines of anthropogenic change. Prioritizing actions to protect valuable fisheries may require fine-scale analyses of the relative value and function of tributaries as nurseries for regional populations. For sectioned otoliths from young-of-the-year (YOY) common snook Centropomus undecimalis; snook), we used laser ablationinductively coupled plasma-mass spectrometry and stable isotope analysis to obtain microchemical signatures distinguishing 9 tributaries (each $<1.0 \mathrm{~km}^{2},<5 \mathrm{~km}$ apart) along a mangrove-tosaltmarsh gradient in the Little Manatee River (LMR), Florida, USA. Using canonical analysis of principal coordinates and jackknifed leave-one-out classification for 123 fish, 70 (56.9\%) were classified correctly based on microchemical signatures, compared with $11.1 \%$ that would have been correctly classified by chance alone $\left(\chi^{2}, \mathrm{p}<0.0001\right)$. Months later, 39 of 40 (98\%) yr-1 snook collected from throughout the LMR were assigned to a YOY nursery tributary based on otolith core signatures. The 3 tributaries making the greatest contribution of YOY snook to the yr-1 population were in pristine, low salinity $(0.5-1.5 \mathrm{psu})$ saltmarshes farthest from the estuary mouth. Since other studies have identified completely different spatial patterns in fish nursery use from year to year, this study should be replicated to assess temporal variation in snook contribution from these nurseries. Nevertheless, this fine-scale application of otolith microchemistry is encouraging for future efforts seeking to protect locations having the greatest likelihood of contributing to survival of fishes that make ontogenetic habitat shifts within coastal ecosystems.
\end{abstract}

KEY WORDS: Otolith microchemistry $\cdot$ Mangrove $\cdot$ Salt marsh $\cdot$ Ecology $\cdot$ Estuary $\cdot$ Centropomus undecimalis $\cdot$ Nursery $\cdot$ Tampa Bay $\cdot$ Connectivity $\cdot$ Contribution analysis

\section{INTRODUCTION}

A particularly vulnerable period in the lives of most fish is the juvenile stage, when individuals are dependent on structured nursery habitats such as reefs, seagrass beds, shorelines, and coastal wetlands, which offer protection from predation and often allow faster growth than do other locations (McIvor et al. 1988, Day et al. 1989). Quantitatively, an aquatic area can be considered a nursery for a regional fish population if its per area contribution of individuals is

*Corresponding author: danceswithfish.jal@gmail.com greater than the average contribution of all areas in the region used by juveniles (Beck et al. 2001). Dahlgren et al. (2006) built on this nursery definition by suggesting that priority should be given more generally to locations if their simple proportional contribution to regional populations is greater than the average of all habitats used by juveniles. The 2 concepts differ only in the significance placed on concentration of individuals in ranking areas for protection, but they tend to complement each other in practical application. For either measure, defining

() The authors 2018. Open Access under Creative Commons by Attribution Licence. Use, distribution and reproduction are unrestricted. Authors and original publication must be credited. 
particular areas by nursery contribution is challenging, especially for longer-lived species that make several ontogenetic habitat shifts. Measuring habitat contribution typically involves marking juveniles within a variety of structurally complex habitats (e.g. salt marshes, mangroves) and tracking them as they grow, survive the nursery phase, and successfully recruit to adult habitats which can be dispersed and distant (e.g. Dahlgren et al. 2006). Microchemical composition of a fish's otoliths is increasingly used as a natural tag for marking an individual, helping to track a fish as it grows and moves among a mosaic of habitats (e.g. Gillanders 2005, Reis-Santos et al. 2013, Schilling et al. 2018). Most estuarine applications of otolith microchemistry have characterized variation at a broad scale (i.e. among places separated by $100 \mathrm{~s}$ of $\mathrm{km}$ ). To better match the known habitat use patterns of our focal species, however, we sought to determine whether otolith microchemistry could be used to quantify contribution rates from habitats used by young-of-the-year (YOY) common snook Centropomus undecimalis (hereafter, snook) to more widely dispersed yr-1 habitats within an estuary.

Several recent studies have applied the Beck et al. (2001) and Dahlgren et al. (2006) concepts to assess the relative contribution rates of nursery areas to adult populations based on otolith microchemistry. As such, connectivity between juvenile and adult populations has been quantified for different habitat types and individual or grouped locations. Accounting for the influence of multiple processes operating between juvenile and adult life stages, however, requires the simultaneous assessment of a suite of factors (Vascsoncelos et al. 2011). In only a few studies to date, data such as juvenile density and condition, physicochemistry, geomorphology, hydrology, nutritional resources, and other attributes have been measured and synthesized to identify what drives differences in contribution trends (Fodrie \& Levin 2008, Chittaro et al. 2009, Vasconcelos et al. 2011). Such a comprehensive view has been proposed as a way of characterizing key components of nursery function (Adams et al. 2006, Vasconcelos et al. 2011). The present study adds to this research by quantifying relationships between the results of our contribution analysis and a suite of ecological, physicochemical and habitat-compositional (e.g. plant community) variables.

Specifically, fish otoliths grow continuously by laying down concentric rings throughout the life of a fish. Remaining chemically inert once formed, these bony structures in the ear can provide a detailed his- tory of a fish's environment. Some of the elements that comprise an individual otolith growth ring are derived from the water mass the fish was living in when the ring was formed, if it resided in a location long enough to acquire a detectable microchemical signature (i.e. at least 15 d) (Campana 1999). Thus, elements in the water mass are permanently stored in the growth rings, and can be used as natural tags, or signatures, representative of particular locations, habitat types, and occupancy periods (Elsdon et al. 2008). As such, the microchemical composition of a sectioned otolith segmented into known ages may reveal the fish's history of occupying different water masses. For example, otolith microchemistry has been used to track the survival of juvenile recruits as they make ontogenetic habitat shifts between (1) mangrove and seagrass nurseries to coral reef adult habitats (Mateo et al. 2010), (2) groups of estuarine nurseries to nearshore coastal adult habitats (ReisSantos et al. 2012, 2013), and (3) freshwater stream nurseries to mainstem riverine adult habitats (Olley et al. 2011). In conducting this research, we sought to expand the diversity and scale of habitat types analyzed in coastal ecosystems used as fish nurseries by otolith microchemistry analysis.

In designing a study using otolith microchemistry to track recruitment-related patterns in habitat use for a population, the study area must be large enough to represent all possible groups contributing to postrecruitment life-history phases (Campana 1999). But individual groups, to be represented within the population of interest, must be far enough apart such that each has a chemically distinct water mass (Campana 2005). Furthermore, the temporal design should allow for distinction of periods during which microchemical signatures remain stable (for example, a 1 to 2 mo climatically uniform periodi Elsdon et al. 2008). Most studies using otolith microchemistry have differentiated whole estuaries separated from each other by long distances distributed along lengthy coastlines $(100-2000 \mathrm{~km}$ ) (Table S3 in the Supplement at www.int-res.com/articles/suppl/ m606p151_supp.pdf). Many estuarine transients, however, make complex ontogenetic habitat shifts between spatially distinct nurseries within an estuary (Day et al. 1989, Litvin et al. 2018). In tropical and subtropical regions, these fishes include species in the families Centropomidae (this study), Haemulidae, Sphyraenidae, Latidae, Lethrinidae, Lutjanidae, Megalopidae, Polynemidae, Sciaenidae, and Sparidae (reviewed in Nagelkerken et al. 2000, Jones et al. 2010, Ley 2014). For these fishes, comparisons among individual groups are needed at a relatively 
fine scale $(<10 \mathrm{~km}$ apart), and possibly within a smaller overall area $\left(<20 \mathrm{~km}^{2}\right)$ within an estuary. We sought to design an intra-estuarine study for snook that met the 3 key aspects of temporal and spatial scale discussed above (i.e. representing all contributing groups, having distinct water masses, and encompassing a limited time period).

Since the growth and development of snook typically involve movements among habitats within an estuary as they transition between life stages, they may be an ideal species for testing hypotheses about the fine-scale, intra-estuarine application of otolith microchemistry (Gilmore et al. 1983). Snook can live for $20 \mathrm{yr}$, and adults occupy a variety of coastal habitats including beaches, rivers, reefs, and most estuarine habitats (Patterson et al. 2005, Winner et al. 2010, Young et al. 2014, Blewett et al. 2017). In contrast to fully mature phases, the juvenile and young adult phases of snook life history are more regionally specialized and vary in traits and behavior between subpopulations, leading to potential variation in habitat use (Stevens et al. 2007). Such variation suggests that trends identified in the present study may differ throughout the distributional range of snook. Snook in west-central Florida spawn in aggregations at passes between Tampa Bay and the Gulf of Mexico; the most important spawning period extends from late May through August (Taylor et al. 1998). Over summer and autumn, snook larvae and young juveniles disperse from the spawning sites to nurseries throughout Tampa Bay, including far upstream in the bay's tidal tributaries (McMichael et al. 1989, Brame et al. 2014). The first major study of juvenile snook populations (20-120 mm standard length [SL]) in Tampa Bay described their habitats as vegetated shorelines (i.e. with overhanging and submersed structure) in non-mainstem areas of tidal rivers and creeks, generally characterized as quiet backwaters sheltered from winds and currents (McMichael et al. 1989). Through direct observation, Peters et al. (1998) showed that juvenile snook (<100 mm SL) aggregate in groups along the shoreline margins of sheltered bays, ponds, and streams. Other studies along Florida's west coast have indicated that these backwaters function as complex networks of mesohabitats that support different developmental stages of juvenile snook in temporal sequence (Stevens et al. 2007, Ley et al. 2010, Barbour et al. 2014, Brame et al. 2014). For example, in one of the minor tributaries of Tampa Bay, stable isotope analysis of muscular tissue revealed that snook began moving from small ponds to adjacent creeks at $40 \mathrm{~mm}$ SL (approximately $60 \mathrm{~d}$ old) (Brame et al. 2014). Approaching $1 \mathrm{yr}$ old (approximately $200 \mathrm{~mm}$ SL), snook begin to mature (first as males), change diets, and expand their home range beyond their nursery area. In doing so, they presumably face an array of hazards, many of them man-made, as they leave the relative safety their nursery and begin to move around the wider estuary. Using microchemistry techniques, we sought to track habitat use as snook transition from the early juvenile (40-60 mm SL) to early adult (200-350 mm SL) stages.

A source of concern for snook is the continued loss of nursery habitat as anthropogenic disturbances (e.g. development, changes in freshwater inflows) continue to alter coastal habitats. Furthermore, climatechange driven sea level rise has been accelerating in the regions occupied by snook, supplanting important coastal wetlands and vegetated shorelines (Raabe et al. 2012, Enwright et al. 2016, Raabe \& Stumpf 2016, Gerlach et al. 2017, Valle-Levinson et al. 2017). To address these threats, current approaches to habitat protection based primarily on land development regulations may be improved by the implementation of place-specific measures; but the present state of knowledge about juvenile snook habitat use may be too broad for the effective implementation of such programs. Thus, our study may demonstrate an approach to science-supported identification of aquatic locations that contribute more juveniles to the later age classes. This information is crucial to the success of conservation programs such as the designation of natural shoreline buffer zones, acquisition of critical tracts of shoreland, and establishment of networks of aquatic protected areas.

Identifying an estuary's prime nursery areas would offer many benefits, but the application of otolith microchemistry at the fine scale needed to do so has not, to our knowledge, been implemented. At a broad scale $\left(>300 \mathrm{~km}^{2}\right)$, recent otolith microchemistry-based studies have indicated the importance of nursery habitats in the less-developed southern portion of Tampa Bay for sustaining snook populations (Rolls 2014). In the present study, we sought to finetune these broad-scale findings by using otolith microchemistry to track habitat use patterns of juvenile snook in greater detail, i.e. for a series of small $\left(<1 \mathrm{~km}^{2}\right)$, neighboring ( $<5 \mathrm{~km}$ apart) locations ('stations') in a single riverine estuary discharging to southern Tampa Bay. Thus, we applied both laser ablation-inductively coupled plasma-mass spectrometry (LA-ICP-MS) and stable isotope analysis (whole pulverized sections) to the analysis of otoliths from YOY snook, and several months later, to otoliths from yr-1 individuals from the same cohort occupying this system. The number of yr-1 snook determined by the 
analysis to have lived in a particular nursery location during their YOY phase served as an index of the location's relative contribution rate (sensu Beck et al. 2001, Dahlgren et al. 2006). By assessing contribution rates and the environmental characteristics associated with each nursery area, we aimed to provide guidance for evaluation of nursery habitat function for this highly valued estuarine transient fish.

\section{MATERIALS AND METHODS}

\section{Study area}

The study area was composed of the tidal portion of the Little Manatee River (LMR) from the mouth to 18 river-kilometers $(\mathrm{rkm})$ upstream, with a lightly developed watershed including a small state park, wilderness areas, low-intensity residential and agricultural lands. Marsh Creek (Stn 1 in Fig. 1) is the exception, with extensive man-made canal systems and modified shorelines (Fig. S2a,b in the Supplement). The LMR has readily identifiable mesohabitats (bayous and tributaries) contiguous with the mainstem, referred to here as 'stations.' Our study area encompassed 5 bayous (lake-like in morphology) and 4 tributaries (creeklike) discharging into the river mainstem. Three of the 5 bayou-type stations have historically been designated as bayous on navigational charts (Mill Bayou, Hayes Bayou, Bolster Bayou), while the other 2 (Dead End, Mangrove) were defined for this study using nicknames. Similarly, 3 of the 4 tributary-type stations are recognized as creeks on boating charts (Marsh Creek, Wildcat Creek, Curiosity Creek), while Tarzan Creek is a nickname created for this study. From this point forward, we will refer to the stations by their first names or the numbers shown in Fig. 1.

The vegetation community gradually changes in species composition along the LMR riverine gradient, with red mangroves Rhizophora mangle and white mangroves Laguncularia racemosa dominating intertidal habitats near the river mouth (Fig. S2c), and intertidal flats (dominated by needle rush Juncus roemerianus and leatherfern Acrostichum spp.) becoming more prominent farther upstream (Fig. S2d-f) (Gerlach et al. 2017).

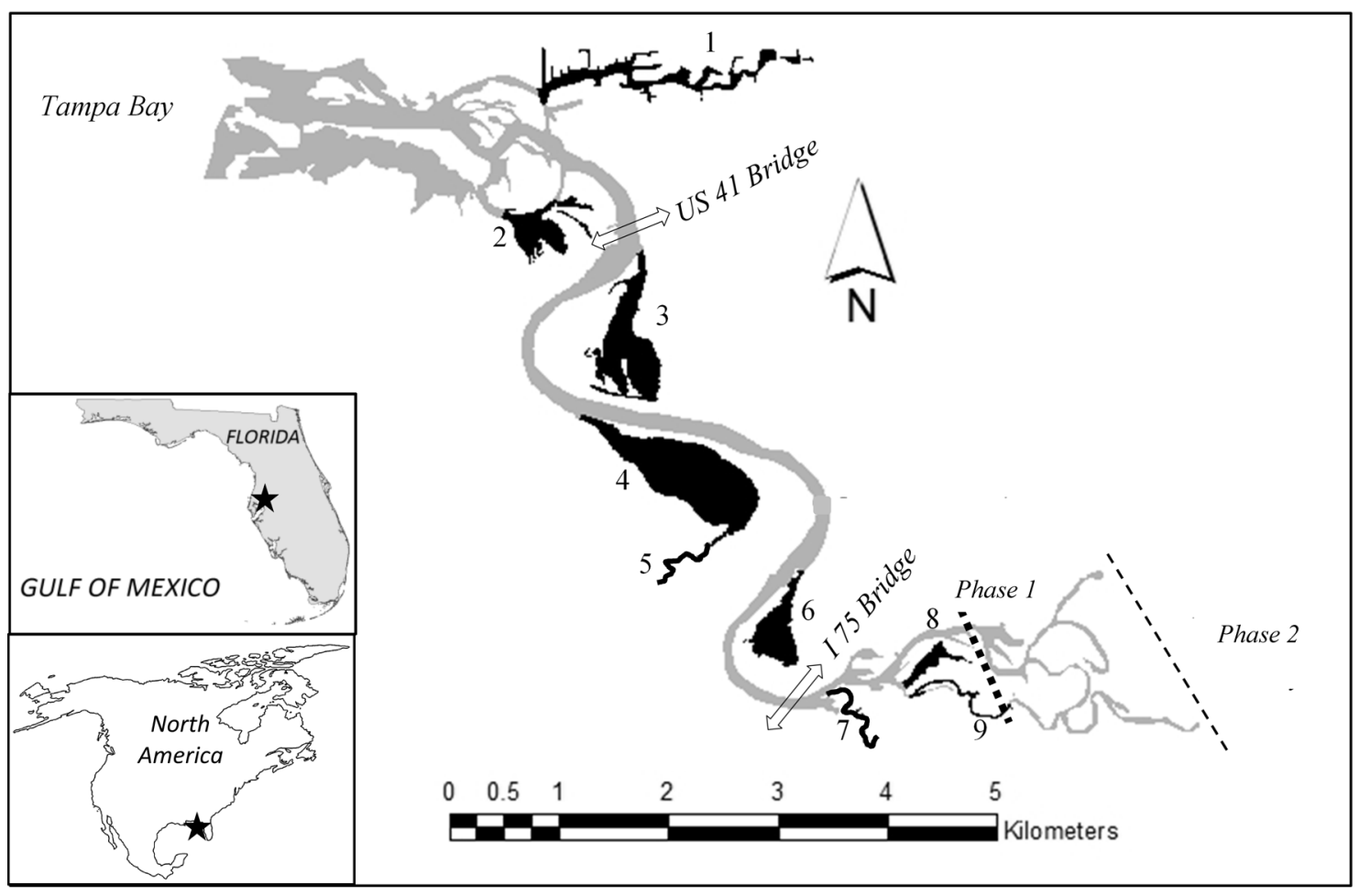

Fig. 1. Study area in the Little Manatee River (LMR). 1: Marsh Creek tributary; 2: Mangrove bayou; 3: Mill Bayou; 4: Hayes Bayou; 5: Wildcat Creek tributary; 6: Bolster Bayou; 7: Curiosity Creek tributary; 8: Dead End bayou; 9: Tarzan tributary (Mangrove, Dead End and Tarzan are nicknames). Black shading: the 9 backwater stations sampled during Phase 1; grey shading: LMR mainstem and side branches connecting the stations to create the expanded sampling area for Phase 2; heavy dashed line: upstream limit of young-of-the-year (YOY) common snook Centropomus undecimalis sampling (Phase 1); lighter dashed line: upstream limit of yr-1 sampling (Phase 2) 
Wetland-transitional and terrestrial vegetation along higher erosional banks of the meandering river mainstem and some creek shorelines consist mainly of Brazilian pepper Schinus terebinthifolius (a shrub) and oaks (Quercus spp.), many with branches overhanging deeper waters (Fig. S2g), providing an alternative fish habitat that is detached from the bank.

The mixed, semi-diurnal tidal regime has a range of $0.60 \mathrm{~m}$ at the mouth (Gerlach et al. 2017), and was observed to maintain this range through the upper limits of the $18 \mathrm{rkm}$ study area. Average depths at low tide in the LMR bayous and tributaries ranged from 0.45 to $1.01 \mathrm{~m}$, while maximum depths ranged from 1.44 to $3.90 \mathrm{~m}$ (see Table S2 in the Supplement). The open aquatic areas of the stations averaged $0.2 \mathrm{~km}^{2}$, ranging from $0.02 \mathrm{~km}^{2}$ in Wildcat to $0.66 \mathrm{~km}^{2}$ in Hayes. Shoreline lengths averaged $4.6 \mathrm{~km}(2.2-$ $11.9 \mathrm{~km}$ ) (Table S2). The swimming distance between the midpoints of neighboring stations (Fig. 1) averaged $2.7 \mathrm{~km}$, with $1.0 \mathrm{~km}$ between the closest stations (Wildcat to Hayes, Tarzan to Dead End). The most isolated station (Stn 6, Bolster) was $3.5 \mathrm{~km}$ from its closest neighbor, Curiosity.

\section{Sampling design and specimen collection}

During Phase I of the study, we sought to characterize the potential nursery areas occupied by snook within the LMR during the autumn 2013 recruitment period based on otolith microchemical signatures. YOY snook (small YOY, 40-59 mm SL) were collected from shorelines of 9 stations (Fig. 1) using a $9.1 \mathrm{~m}$ center bag seine (Fig. S2a). Long-term (1996-2015) snook catch per unit effort (CPUE) data obtained in monthly trawl and river-seine surveys under the Florida Fish and Wildlife Research Institute's (FWRI) Fisheries-Independent Monitoring (FIM) program lent support to the concept that these locations were the most likely nurseries for snook in the LMR. Each station was divided into 4 sectors of equal shoreline length and during each of 4 sampling trips (start dates: 4 and 17 September, 4 and 25 October 2013), at least one sample was obtained in each sector of each station. Ancillary data were collected for each net sample $(\mathrm{n}=173 \mathrm{ob}-$ servations) at several locations in the swept and adjacent areas, including salinity, habitat features, depths, and latitude/longitude. In recording habitat features for each sampling site, we considered the $2 \mathrm{~m}$ wide landward fringe and the entire swept area, characterizing composition for $25-50 \mathrm{~m}^{2}$. From the inventory of early YOY snook collected (40-59 mm SL, $\mathrm{n}=370)$, a subset of 127 YOY was retained for analysis, comprising 14 or 15 snook station ${ }^{-1}$ (Fig. S1a in the Supplement). Applying a linear age-length regression model to a count of the daily rings in a sample of clearly readable, sectioned YOY snook otoliths $(n=100)$, we calculated an average growth rate of $0.61 \mathrm{~mm} \mathrm{SL} \mathrm{d}^{-1}$. This growth rate was used in conjunction with the von Bertalanffy growth model developed for west coast Florida populations by Taylor et al. (2000) to estimate the target size and age of yr-1 samples to be collected later in the year (Phase 2).

During Phase 2, a total of 40 yr-1 fish (196-335 mm SL) were obtained from monthly FIM river-seine surveys and FWRI monthly electrofishing surveys. We selected yr-1 specimens within the 9 stations, as well as from previously unsampled side channels and mainstem habitats. Thus, Phase 2 sampling sites were widely distributed along the estuarine gradient (Fig. S1b). Upon collection, all fish were stored on ice and then frozen until further processing. In the laboratory, snook were measured (SL) and weighed (wet weight, g) and both sagittal otoliths were extracted and stored in clean glass vials awaiting final preparation and microchemical analysis.

\section{Otolith microchemical analysis}

All otolith preparation was conducted using tracemetal grade materials and methods. Sagittal otoliths of YOY and yr-1 fishes were removed and cleaned of residual tissue using chemically inert ceramic-tipped forceps, rinsed in ultrapure water $(18.2 \mathrm{M} \Omega)$, dried, and stored for later processing. For further cleaning, otoliths were placed inside clean well-plates within a Class 100 metal-free laminar flow bench, scrubbed using a clean toothbrush, immersed in $36 \%$ ultrapure hydrogen peroxide for $3 \mathrm{~min}$, and rinsed 3 times in ultrapure water between each step. Clean otoliths were dried within clean vials for $24 \mathrm{~h}$ inside a Class 100 laminar flow bench, mounted on clean petrographic slides using Crystal Bond ${ }^{\mathrm{TM}} 509$ and thinsectioned through the core to a thickness of $1 \mathrm{~mm}$ using a Buehler Isomet ${ }^{\circledR}$ low-speed saw. Thin sections were polished using 3 sequential grades of polishing paper $(68,21.8$ and $3 \mu \mathrm{m}$ particle diameters) to reveal the exact core and daily rings of each otolith. The final thin sections were re-mounted onto clean petrographic slides, thoroughly rinsed with ultrapure water, and sonicated for 5 min to remove any impurities introduced during the sectioning process. Final petrographic slides with mounted thin sections were fully dried inside a Class 100 laminar flow bench 
before being transferred to the LA-ICP-MS for chemical analysis.

A PhotonMachines Analyte.193 excimer UV laser ablation system, connected to an Agilent $7500 \mathrm{CX}$ quadropole inductively coupled plasma-mass spectrometer was used to assess the chemical composition of otolith samples. For each sample, a suite of 24 isotopes was measured: ${ }^{7} \mathrm{Li}_{1}{ }^{23} \mathrm{Na},{ }^{24} \mathrm{Mg},{ }^{31} \mathrm{P},{ }^{45} \mathrm{Sc}$, ${ }^{51} \mathrm{~V},{ }^{53} \mathrm{Cr},{ }^{55} \mathrm{Mn},{ }^{57} \mathrm{Fe}^{59}{ }^{50},{ }^{60} \mathrm{Ni}^{63}{ }^{63} \mathrm{Cu},{ }^{64} \mathrm{Zn},{ }^{72} \mathrm{Ge},{ }^{85} \mathrm{Rb}$, ${ }^{88} \mathrm{Sr},{ }^{89} \mathrm{Y},{ }^{114} \mathrm{Cd},{ }^{118} \mathrm{Sn},{ }^{137} \mathrm{Ba},{ }^{197} \mathrm{Au},{ }^{208} \mathrm{~Pb},{ }^{232} \mathrm{Th}$, and ${ }^{238} \mathrm{U}$. These elements were selected based on their chemical properties, which render them more readily incorporated into otolith material at detectable concentrations over the fish's life; the isotopes were selected as they were less likely to have isotopic interferences during chemical analysis, as well as their potential to reflect environmental gradients within the study area (e.g. pollutants, salinity gradients). Two certified reference materials were analyzed after every 10th sample acquisition (NIST-612 and NIST-614) and operating parameters on the ICPMS were tuned prior to each sample run to optimize stability and sensitivity, minimize isotopic interferences, and reduce mass-specific fractionation of isotopes. To optimize external precision, the ICP-MS was tuned during a line scan on the NIST-612 (10 $\mu \mathrm{m}$ $\mathrm{s}^{-1}$ scan speed, $108 \mu \mathrm{m}$ beam diameter; $5 \mathrm{~Hz}$ repetition rate) to consistently deliver $\mathrm{ThO}+/ \mathrm{Th}+$ values below $6 \%$ (indicating that oxide interferences were negligible) and relative standard deviation (RSD) values below $8 \%$ for measured analytes (indicating that repeated analyses of the analytes were consistent). The use of calcium as an internal standard allowed for the correction of sources of bias such as sensitivity drift, matrix effects, as well as variations in the mass of material ablated among samples and standards (Longerich et al. 1996). Samples were run in randomized blocks to avoid introducing any potential day-to-day variations in instrument sensitivity into the analyses.

To acquire the elemental fingerprint from each YOY otolith, 3 replicate spots were ablated on each otolith along the proximal-ventral edge, adjacent to the sulcal groove, for $60 \mathrm{~s}(50 \mu \mathrm{m}$ beam diameter; $10 \mathrm{~Hz}$ repetition rate); ablated material was sent to the ICP-MS to be separated and measured according to mass-to-charge ratios. Prior to each ablation, the target area was pre-ablated with a $147.9 \mu \mathrm{m}$ square at $1 \mathrm{~Hz}$ repetition rate and $50 \mu \mathrm{m} \mathrm{s}^{-1}$ to remove any potential surface contaminants. To prevent crosscontamination of samples, a washout period of $30 \mathrm{~s}$ was applied after each sample ablation to ensure that all material was sufficiently flushed from the system before subsequent ablations. This was followed by an additional $30 \mathrm{~s}$ of gas blank sampling to allow for measurement of background concentrations prior to each sample acquisition.

Otoliths of yr-1 specimens were analyzed using the same LA-ICP-MS settings as described above, with the exception that a series of 4 spots was ablated along a core-to-edge transect, the length of which corresponded with the material accreted during the YOY period. Specifically, to acquire the chemical signature associated with the YOY period of interest within each yr-1 otolith, 4 spots (50 $\mu \mathrm{m}$ each) were ablated beginning at $350 \mu \mathrm{m}$ and ending at $550 \mu \mathrm{m}$ from the core, as these were the minimum and maximum core-to-edge distances observed in the YOY otoliths previously analyzed. A single chemical signature, representing the YOY period of each yr-1 fish, was generated by averaging the data acquired from each spot that fell within 1 standard deviation of the mean of all spots from the transect. In this way, the full period during which YOY material was accreted was also considered in yr-1 otoliths.

Post-analysis data processing involved conversion of the raw elemental counts-per-second data into element per ${ }^{43} \mathrm{Ca}$ ratios $\left(\mathrm{mmol} \mathrm{mol}^{-1}\right)$ using the Fathom Toolbox for MatLab (Jones 2012). Grubbs' test ( $p=$ 0.05 ) was used to remove any anomalous background-corrected signal data. Instrument detection limits for each isotope are listed in Table 1. For the few instances in which data were below detection limits, original data were retained to avoid introducing overly conservative data estimates and bias associated with removal and substitution methods (Helsel 1990, 2006).

For stable isotope analysis, otolith sections analyzed for trace elements were pulverized with a mortar and pestle, weighed using a microbalance, and analyzed for $\delta^{13} \mathrm{C}$ and $\delta^{18} \mathrm{O}$ using a Thermo Fisher MAT 253 isotope ratio mass spectrometer in continuous mode coupled to a Thermo Fisher Gas Bench-II. Three reference materials were used to correct for drift (BORBA), amplitude variations (TSF-1), and instrument accuracy (ChiCal). Values were reported in standard delta notation relative to the Vienna Pee Dee Belemnite isotope scale.

\section{Microchemical characterization of YOY nurseries}

Prior to further analysis, the elemental variables $\left(x=\right.$ molar ratio of an element to calcium, $\left.\mathrm{mmol} \mathrm{mol}^{-1}\right)$ were subjected to evaluation of assumptions. First, histograms and related tests revealed that each of the 
Table 1. Inductively coupled plasma-mass spectrometry (ICP-MS) limits of detection (LOD_min) for 24 elements used in the analysis of young-of-the-year (YOY) and yr-1 common snook otolith microchemistry

\begin{tabular}{|lc|}
\hline Elements & LOD_min $(\mathrm{ppm})$ \\
\hline${ }^{7} \mathrm{Li}$ & 0.0359 \\
${ }^{23} \mathrm{Na}$ & 7.4898 \\
${ }^{24} \mathrm{Mg}$ & 0.0358 \\
${ }^{31} \mathrm{P}$ & 5.0151 \\
${ }^{45} \mathrm{Sc}$ & 0.0707 \\
${ }^{51} \mathrm{~V}$ & 0.0406 \\
${ }^{53} \mathrm{Cr}$ & 0.5734 \\
${ }^{55} \mathrm{Mn}$ & 0.1365 \\
${ }^{57} \mathrm{Fe}$ & 1.8625 \\
${ }^{59} \mathrm{Co}$ & 0.0225 \\
${ }^{60} \mathrm{Ni}$ & 0.1141 \\
${ }^{63} \mathrm{Cu}$ & 0.2682 \\
${ }^{64} \mathrm{Zn}$ & 0.1424 \\
${ }^{72} \mathrm{Ge}$ & 0.2445 \\
${ }^{85} \mathrm{Rb}$ & 0.0322 \\
${ }^{88} \mathrm{Sr}$ & 0.0036 \\
${ }^{89} \mathrm{Y}$ & 0.0027 \\
${ }^{114} \mathrm{Cd}$ & 0.0523 \\
${ }^{118} \mathrm{Sn}$ & 0.0328 \\
${ }^{137} \mathrm{Ba}$ & 0.0208 \\
${ }^{197} \mathrm{Au}$ & 0.0106 \\
${ }^{208} \mathrm{~Pb}$ & 0.0407 \\
${ }^{232} \mathrm{Th}$ & 0.0034 \\
${ }^{238} \mathrm{U}$ & 0.0024 \\
\hline
\end{tabular}

variables displayed a normal distribution of errors and homogeneity of variances. Second, since outlier samples can have a strong distortional influence on multivariate statistical analyses (Tabachnick \& Fidell 2013), we plotted the observations for each station (separately) on the first 2 axes derived from principal components analysis (PCA), and then graphically overlaid each plot with a prediction interval ellipse enclosing $99 \%$ of the station's observations (Statistica v.10; StatSoft 2008). YOY snook samples that did not fall within the prediction interval ellipse were assumed to be possible outliers (Chittaro et al. 2009). Each variable was normalized before statistical analyses were conducted.

Distance-based permutational multivariate analysis of variance (PERMANOVA; Anderson 2001, Anderson et al. 2008) was used to assess variation in the elemental and stable isotopic composition of sample otoliths (Reis-Santos et al. 2012, 2013, Schilling et al. 2018) among the 9 stations in the LMR (Fig. 1). Using PERMANOVA, variation can be partitioned into factors using a distribution-free, permutation-based approach. Advantages of PERMANOVA include its lack of sensitivity to correlations among the response variables and capacity to handle designs in which the number of samples is not much greater than the number of variables (Anderson 2001). The model applied also accounted for temporal effects based on trip $(\mathrm{n}=4)$. A 2 -way crossed $F$-ratio test was calculated (pseudo- $F$ ), comparing the data-derived values with the null hypothesis of no differences between stations during each trip (9999 permutations). This analysis allowed for the identification of spatiotemporal interactions (Clarke et al. 2009, Schilling et al. 2018). PERMANOVA was also used to conduct univariate tests for the 26 individual variables.

Elemental and stable isotopic signatures recorded from the otoliths of YOY juvenile snook were analyzed for 3 alternative groupings: (1) stations (9 categories), (2) regions (3 categories: downstream, midstream, upstream), and (3) habitat types (2 categories: tributaries, bayous). In 3 separate analyses, using the 26 variables, an optimal subset for characterizing each grouping was identified by using a distance-based linear modeling routine (DISTLM) and corrected Akaike's information criterion $\left(\mathrm{AIC}_{\mathrm{c}}\right)$ selection (Akaike 1973, McArdle \& Anderson 2001, Burnham \& Anderson 2002). Canonical analysis of principal coordinates (CAP) was implemented with Euclidean distances to classify each of the YOY samples back to the group from which they were originally collected (Anderson \& Robinson 2003, Anderson \& Willis 2003, Anderson et al. 2008, Chittaro et al. 2009). As a constrained ordination for discriminating among a priori groups, CAP provides an unbiased measure of how distinct groups are in multivariate space (Fairclough et al. 2011, 2013, Reis-Santos et al. 2015). CAP finds principal coordinate (PCO) axes through the variable-derived cloud of points that best separate the groups, then uses a sequential process for choosing the minimum number $(m)$ of PCO axes required to maximize the probability of correctly classifying each sample to its category. It uses permutation-based cross-validation analysis to re-calculate classification success values as each new PCO axis is added. For each step, the cross-validation routine extracted one sample at a time and checked the ability of the model to correctly re-classify that sample into its appropriate category (a jackknife, leaveone-out procedure). The final CAP model was evaluated for validity using 2 diagnostic tools. First, a chi-squared test was used to determine whether the cross-validation success was substantially greater than that which would be expected by chance. For example, in the case of no experimental effect, each of the groups would be allocated an equal number of

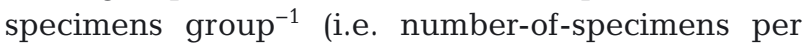
number-of-groups; Fowler et al. 1998). Second, a per- 
mutation test was used to evaluate the validity of the model calculated from the sum of the squared canonical correlations for each CAP (i.e. permutation test trace statistic); this test criterion is equivalent to the Pillai's trace statistic.

\section{Contribution rates}

The contribution analysis was only conducted for the 9-station model (see 'Results'). CAP was used to assign each yr-1 snook to the station in which it had resided as a YOY recruit (Anderson \& Robinson 2003, Anderson et al. 2008). Additional samples may be placed onto the canonical axes of an existing CAP model and thereby facilitate the classification of the new unknown-origin samples to an existing group (Schilling et al. 2018). Specifically, each yr-1 sample was microchemically characterized by calculating its position in the multidimensional space as defined by the YOY samples; each was then assigned to the station with the shortest centroid distance from the sample's position. To evaluate goodness-of-fit for the CAP assignment model, we surveyed the centroidto-sample distances for each observation and eliminated yr-1 samples whose distance was more than 3 times the average of all distances.

We calculated the net distance moved during the 2 sequential age classes in the cohort. The shortest aquatic route between the mid-point of each assigned YOY nursery station and the actual yr-1 collection location was measured on an aerial photograph using ArcMap (ESRI 2012).

The yr-1 assignments were used first to evaluate the proportion of individuals that originated from each station, indicating which were relatively more valuable as nurseries for YOY snook (Dahlgren index; Dahlgren et al. 2006). Second, the relative contribution of each station was standardized by shoreline length (i.e. a modified version of the area-standardized Beck index; Beck et al. 2001). As such, the entire shoreline edge (perimeter) for each station was measured (as depicted in Fig. 1) using ArcMap (ESRI 2012) to quantify the amount of nursery area available per station. These values were summed for all 9 backwater stations to estimate the regional nursery habitat available. The number of yr-1 individuals assigned to each station was divided by the proportion of nursery area available in that station. Ultimately, a station's priority ranking was high if the value of the station's per-area contribution was greater than the average contribution across all stations. Such stations met the Beck definition of nursery. A similar ranking was developed for the Dahlgren index. Chi-squared tests were used to determine whether the observed contributions were substantially greater or lesser than equivalent for each station.

\section{Nursery function analysis}

Relationships between the nursery contribution rates for each station and the environmental conditions present during the YOY recruitment period (autumn 2013) were explored using Pearson correlation and multiple regression tests (Statistica v.10; StatSoft 2008). We used a set-based procedure (Anderson \& Gribble 1998), assigning each variable to 1 of 3 sets and thereby enabling examination of a range of factors likely to influence nursery success. Specifically, each station's area-standardized (Beck index) contribution rate was compared with 3 sets of explanatory variables, including (1) Set 1: ecological factors: fish condition, density, finfish bycatch, plant bycatch; (2) Set 2: physicochemical factors: salinity, aquatic area, shoreline slope, whole station depth, distance to the estuary mouth; and (3) Set 3: shoreline features: hardened (riprap \%), Acrostichum spp., $J$. roemerianus, $S$. terebinthifolius, Quercus spp., $R$. mangle, and L. racemosa.

Station-averaged values for fish condition and sampling site density were calculated using 370 small YOY snook (40-59 mm SL). As an indicator of fish condition, we used the condition anomaly index $\left(R_{W}\right)$ :

$$
R_{W}=100 \times\left(R / W_{\text {Pred }}\right)
$$

where $R$ is the set of residual values (i.e. differences between the predicted and actual weight-at-length) for each fish (Roegner \& Teel 2014). Predicted weight $\left(W_{\text {Pred }}\right)$ for each individual was determined using the power equation:

$$
W_{\text {Pred }}=\mathrm{a} \times L^{b}
$$

where $a$ and $b$ are coefficients derived empirically for the specimens and $L$ is the fish's standard length (King 2007).

\section{RESULTS}

\section{Microchemical characterization of YOY nurseries}

PERMANOVA detected highly significant $(\mathrm{p}<$ 0.0001) multivariate differences among the 9 stations based on otolith composition using all 24 elements 
and 2 stable isotopes $\left(\delta^{13} \mathrm{C}\right.$ and $\left.\delta^{18} \mathrm{O}\right)$ (Table 2a). A marginally non-significant $(\mathrm{p}=0.0727$ ) interaction term showed that a temporal effect occurred in a few cases, but detailed analysis of the temporal patterns for each station (post hoc permutation tests) showed that trip had a significant effect for only 4 out of 47 paired comparisons. The 4 cases with significant trip within station interactions occurred in Bolster, Dead End, and Tarzan and each involved a significant temporal difference between trips 1 or 2 (4 or 17 September) versus trip 4 (25 September). Since these 4 interactions did not indicate a strong systematic trend in the overall analysis, temporal effects were not considered in subsequent analyses.

Table 2. PERMANOVA results for analysis of the microchemical composition of 127 young-of-the-year (YOY) common snook otoliths. (a) Multivariate tests of station by trip; (b) univariate results by station with bold used to highlight the variables which varied significantly among the stations. Mean and standard deviations are expressed as elemental ratios to calcium $\left(\mathrm{mmol} \mathrm{mol}{ }^{-1}\right)$. For isotope numbers, refer to Table 1

\begin{tabular}{|c|c|c|c|c|c|c|}
\hline Source & $\mathrm{df}$ & $F$ & $\mathrm{p}$ & \multicolumn{3}{|c|}{ Post hoc test: trips within stations } \\
\hline Station & 8 & 1.76 & $<0.0001$ & \multirow{3}{*}{\multicolumn{3}{|c|}{4 tests with $\mathrm{p}<0.05$ out of 47 total }} \\
\hline Trip & 3 & 1.96 & 0.0009 & & & \\
\hline Station $\times$ Trip & 22 & 1.15 & 0.0727 & & & \\
\hline \multicolumn{7}{|c|}{ (b) Univariate results by station $(\mathrm{n}=9)$} \\
\hline Variables & \multicolumn{2}{|c|}{$\begin{array}{c}\text { Mean } \\
\left(\mathrm{mmol} \mathrm{mol}^{-1}\right)\end{array}$} & \multicolumn{2}{|c|}{$\begin{array}{l}\text { Standard deviation } \\
\left(\mathrm{mmol} \mathrm{mol}^{-1}\right)\end{array}$} & $F$ & $\mathrm{p}$ \\
\hline$\delta^{13} \mathrm{C}$ & \multicolumn{2}{|c|}{-12.4454197} & \multicolumn{2}{|c|}{1.3839818} & 5.88 & $<0.0001$ \\
\hline$\delta^{18} \mathrm{O}$ & \multicolumn{2}{|c|}{-3.9772005} & \multicolumn{2}{|c|}{0.4255148} & 2.80 & 0.0070 \\
\hline $\mathrm{Au}$ & \multicolumn{2}{|c|}{0.0000067} & \multicolumn{2}{|c|}{0.0000011} & 0.80 & 0.6051 \\
\hline Ba & \multicolumn{2}{|c|}{0.0033090} & \multicolumn{2}{|c|}{0.0020042} & 7.35 & $<0.0001$ \\
\hline $\mathrm{Cd}$ & \multicolumn{2}{|c|}{0.0000721} & \multicolumn{2}{|c|}{0.0000124} & 1.46 & 0.1808 \\
\hline $\mathrm{Co}$ & \multicolumn{2}{|c|}{0.0002379} & \multicolumn{2}{|c|}{0.0000474} & 1.43 & 0.1895 \\
\hline $\mathrm{Cr}$ & \multicolumn{2}{|c|}{0.0014904} & \multicolumn{2}{|c|}{0.0001972} & 0.53 & 0.8333 \\
\hline $\mathrm{Cu}$ & \multicolumn{2}{|c|}{0.0006882} & \multicolumn{2}{|c|}{0.0001281} & 1.08 & 0.3850 \\
\hline $\mathrm{Fe}$ & \multicolumn{2}{|c|}{0.3577962} & \multicolumn{2}{|c|}{0.0386811} & 0.73 & 0.6685 \\
\hline $\mathrm{Ge}$ & \multicolumn{2}{|c|}{0.0004472} & \multicolumn{2}{|c|}{0.0000686} & 0.56 & 0.8126 \\
\hline $\mathrm{Li}$ & \multicolumn{2}{|c|}{0.0011398} & \multicolumn{2}{|c|}{0.0004456} & 1.89 & 0.0671 \\
\hline $\mathrm{Mg}$ & \multicolumn{2}{|c|}{0.1324871} & \multicolumn{2}{|c|}{0.0269152} & 0.66 & 0.7288 \\
\hline Mn & 0.00 & 903 & 0.0 & 016342 & 6.07 & $<0.0001$ \\
\hline $\mathrm{Na}$ & 13.41 & 912 & 0.9 & 941973 & 3.41 & 0.0015 \\
\hline $\mathrm{Ni}$ & 0.00 & 233 & 0.0 & 000608 & 0.56 & 0.8097 \\
\hline $\mathrm{P}$ & 0.31 & 187 & 0.1 & 249170 & 0.80 & 0.6016 \\
\hline $\mathrm{Pb}$ & 0.00 & 729 & 0.0 & 000084 & 0.53 & 0.8304 \\
\hline $\mathbf{R b}$ & 0.00 & 767 & 0.0 & 000881 & 5.85 & $<0.0001$ \\
\hline $\mathrm{Sc}$ & 0.00 & 395 & 0.0 & 000321 & 0.64 & 0.7419 \\
\hline $\mathrm{Sn}$ & 0.00 & 891 & 0.0 & 000300 & 0.38 & 0.9316 \\
\hline $\mathbf{S r}$ & 2.95 & 728 & 0.4 & 488452 & 4.04 & 0.0003 \\
\hline Th & 0.00 & 020 & 0.0 & 000003 & 0.62 & 0.7626 \\
\hline $\mathrm{U}$ & 0.00 & 016 & 0.0 & 000002 & 1.15 & 0.3340 \\
\hline V & 0.00 & 025 & 0.0 & 000133 & 0.92 & 0.5062 \\
\hline $\mathrm{Y}$ & 0.00 & 070 & 0.0 & 000013 & 0.79 & 0.6158 \\
\hline $\mathrm{Zn}$ & 0.00 & 662 & 0.0 & 008313 & 0.53 & 0.8294 \\
\hline
\end{tabular}

When the variables were tested individually, univariate ANOVA results revealed significant $(\mathrm{p}<0.01)$ differences in variability among stations for a subset of only 7 variables $\left(\delta^{13} \mathrm{C}, \delta^{18} \mathrm{O}, \mathrm{Ba}, \mathrm{Mn}, \mathrm{Na}, \mathrm{Rb}\right.$, and $\left.\mathrm{Sr}\right)$. Pearson correlation among pairs of variables was high for only one pair: $\delta^{13} \mathrm{C}$ vs. $\delta^{18} \mathrm{O}(\mathrm{r}=0.8)$ indicating little redundancy among the remainder of the variables.

To identify multivariate outliers, focusing on each station separately, PCA analyses using all 26 variables detected 4 samples which fell outside $99 \%$ prediction interval ellipses (PCA plots not shown). These outliers were removed from subsequent analyses (Marsh \#398 and \#706, Hayes \#490, Dead End \#1092; locations of outliers mapped in Fig. S1a in the Supplement).

To select the final set of variables for classification of each YOY snook by station, DISTLM calculated models for every combination of the 26 variables, ultimately ranking each model based on the $\mathrm{AIC}_{\mathrm{c}}$ criteria. Each of the 10 top-ranked solutions (scoring between -112.07 and -112.85 ) included 5 of the variables $\left(\delta^{13} \mathrm{C}, \mathrm{Ba}\right.$, $\mathrm{Mn}, \mathrm{Rb}$, and $\mathrm{Sr}$ ) together explaining $18.5 \%$ of the variation in the data. Three other variables were included in various combinations in the 10 topranking models: $\mathrm{Li}, \mathrm{Na}$, and $\mathrm{Co}$. Boxand-whisker plots for each of these 8 key variables indicated significant and unique trends in relation to the variable's distribution by station (Fig. 2). For example, Co (Fig. 2d) was rather uniformly distributed among the stations except at Mill, where it was in significantly lower concentration. In contrast, the distribution of $\mathrm{Ba}$ (Fig. 2g) was gradient-related, present in significantly lower concentrations in all 4 stations located farthest downstream (Stns 1, 2, 3, and 4) but present in higher concentrations at all upstream stations (Stns 6, 7, 8, and 9 plus Stn 5, Wildcat). Distributional trends in $\mathrm{Rb}$ and $\mathrm{Mn}$ (but not $\mathrm{Sr}$ ) were also gradient-related (Fig. 2c,e,f).

We conducted CAP analyses for each of the top $10 \mathrm{AIC}_{\mathrm{C}}$ models, obtaining cross-validation success rates ranging from 48.8 to $56.9 \%$. Finally, we selected the model with the greatest success rate $(56.9 \%)$, which characterized distinctions among the sta- 

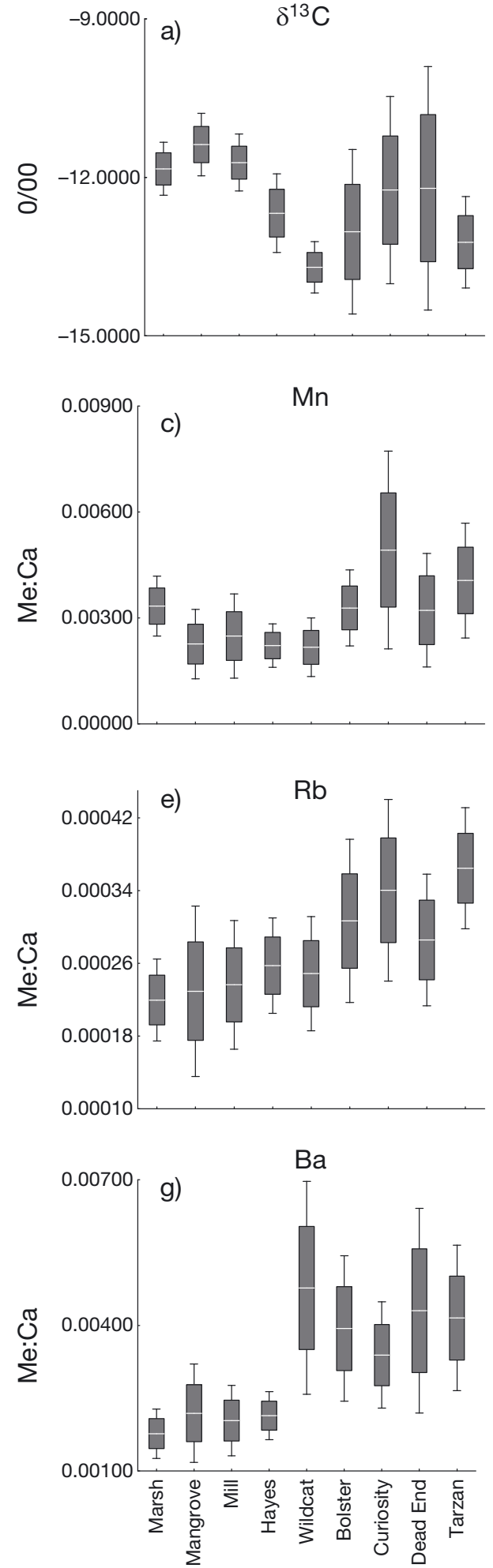
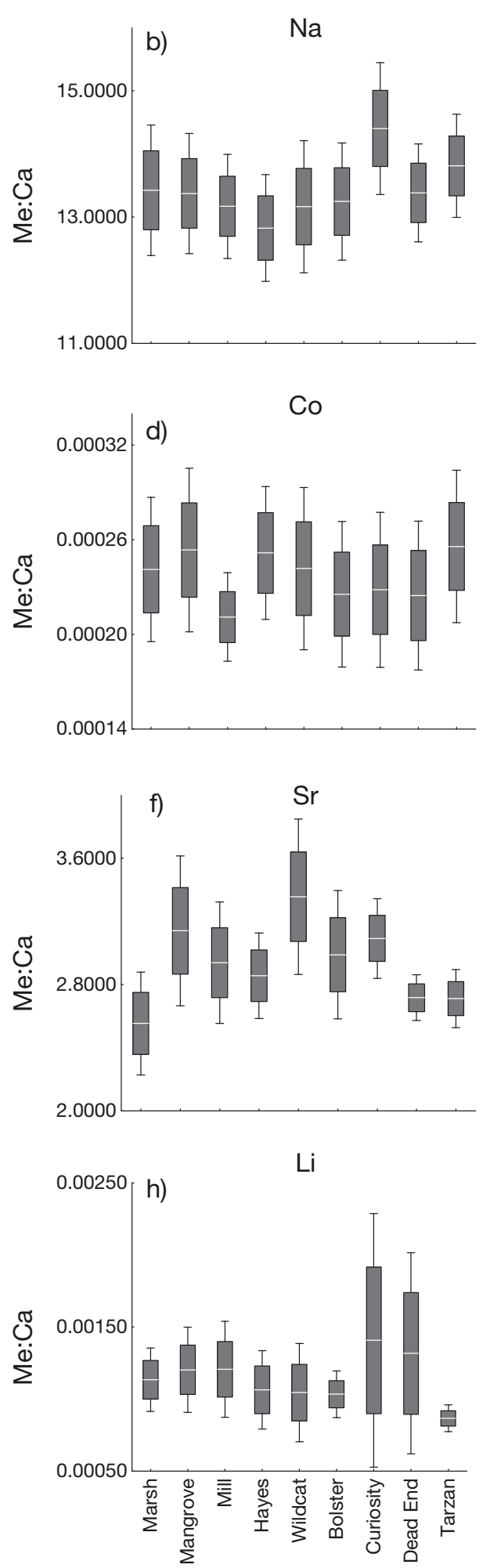

\section{Station}

Fig. 2. Elemental ratio and stable isotope data for 123 young-of-the-year (YOY) otoliths from common snook collected from the Little Manatee River. Boxes represent $95 \%$ confidence intervals around the mean (horizontal white line); whiskers represent the standard deviation ranges for each nursery station. The plots represent the 7 elements (a-g) used in the canonical analysis of principal coordinates (CAP) (see Table 3) plus lithium (h). Me:Ca refers the ratio of the micromolar concentration of the element to the molar concentration of calcium; $0 / 00$ refers to parts per mille 
tions by inclusion of 7 variables making up the otolith signature: $\delta^{13} \mathrm{C}, \mathrm{Ba}, \mathrm{Mn}, \mathrm{Co}, \mathrm{Na}, \mathrm{Rb}$, and $\mathrm{Sr}$ (Table 3). The overall validity of this CAP model was highly significant, based on the permutation test trace statistic (1.71, p < 0.0001). Furthermore, sizes of the canonical correlations with the first 2 CAP axes were reasonably strong $\left(\delta_{1}=0.73\right.$ and $\left.\delta_{2}=0.68\right)$, supporting the hypothesis of discrimination among the stations (Table S1a in the Supplement). Although we obtained an overall cross-validation success value of $56.9 \%$, individual stations ranged from 21.4 to $84.6 \%$ correctly classified (Table 3). Overall, for 7 of the 9 stations, $\geq 50 \%$ of the snook were correctly classified, indicating that the 9-station model accounted for a substantial portion of the variation in the data. Furthermore, the chi-squared analysis was strong and significant $\left(\chi_{8}^{2}=264.5, \mathrm{p}<0.0001\right)$, indicating that the number of observations correctly classified was large (5 times greater) relative to the number expected if samples were distributed homogeneously.

Classification results showed that where incorrectly classified, many of the fish were assigned to an adjacent or neighboring station (\% correct: off-byone; Table 3). For example, for fish collected from Mangrove, 4 YOY snook were assigned to Mill, the closest neighbor to Mangrove. Similarly, 3 YOY snook collected in Tarzan were assigned to the adjacent station, Dead End. Based on the off-by-one approach, $73.2 \%$ of the YOY snook were correctly assigned back to their station of origin or to its neighboring station.

Since our ability to distinguish otolith signatures by individual station was moderately successful $(56.9 \%)$, we also repeated the variable selection and cross-validation procedure for 2 types of mega-groups consisting of multiple stations, attempting to increase the number of fish correctly allocated (Table 4). At the regional scale, using 11 variables, samples grouped by downstream, midstream, and upstream had an overall cross-validation success rate that was only marginally better $(62.6 \%)$ than the 9-station model (56.9\%). By habitat type, using 6 variables, samples grouped by bayou or tributary had an overall crossvalidation success rate that was also $62.6 \%$. Thus, since pooling the samples by region or habitat type did not substantially improve cross-validation success, we determined that the 9-station model (Table 3) was most appropriate given our data and the fine-scale specificity sought in this study.

In the CAP plot, distribution of the samples by station was depicted with symbols for the first 2 axes derived in the analysis representing most of the variation explained in the model (95\%; Table S1a) (Fig. 3). With 9 groups, 7 variables, and 123 samples, the configuration of the plot is complex. For example, all samples from Marsh (which was largely correctly classi-

Table 3. Station cross-validation matrix derived from canonical analysis of principal coordinates (CAP) (detailed results in Table S1 in the Supplement). The values in the matrix represent the number of common snook otolith samples collected at a given station (listed in the first column) that were assigned to a station based on microchemistry analysis (as listed in the top row of stations), e.g. 11 samples that were collected in Marsh were microchemically assigned to Marsh, representing $84.6 \%$ of the 13 samples originally collected in Marsh. The 7 variables used in the CAP were $\delta^{13} \mathrm{C}, \mathrm{Ba}, \mathrm{Mn}, \mathrm{Co}, \mathrm{Na}, \mathrm{Rb}$, and $\mathrm{Sr}$. Chisquared analysis compared the number of samples correctly assigned to a station (No. correct by CAP) vs. number expected. The permutation-test trace statistic was based on the full CAP model (details provided in Table S1). Shaded cells: cases in which fish were allocated to a station which was adjacent to the original station of collection (\% correct off-by-one); final shaded column: percent correctly allocated based on these off-by-one totals

\begin{tabular}{|c|c|c|c|c|c|c|c|c|c|c|c|c|c|}
\hline $\begin{array}{l}\text { Station } \\
\text { collected }\end{array}$ & Marsh & $\begin{array}{l}\text { Man- } \\
\text { grove }\end{array}$ & $\begin{array}{l}\text { tation } \\
\text { Mill }\end{array}$ & $\begin{array}{c}\text { assignec } \\
\text { Hayes }\end{array}$ & $\begin{array}{c}\text { based } \\
\text { Wild- } \\
\text { cat }\end{array}$ & $\begin{array}{l}\text { on micr } \\
\text { Bolster }\end{array}$ & $\begin{array}{l}\text { ochemistry } \\
\text { Curiosity }\end{array}$ & $\begin{array}{l}\text { Dead } \\
\text { End }\end{array}$ & Tarzan & $\begin{array}{c}\text { No. } \\
\text { correct } \\
\text { by } \\
\text { CAP }\end{array}$ & $\begin{array}{l}\text { No. } \\
\text { ana- } \\
\text { lyzed }\end{array}$ & $\begin{array}{c}\% \\
\text { correct } \\
\text { (directly } \\
\text { allocated) }\end{array}$ & $\begin{array}{c}\% \\
\text { correct } \\
\text { (off-by- } \\
\text { one) }\end{array}$ \\
\hline 1. Marsh & 11 & 1 & 1 & 0 & 0 & 0 & 0 & 0 & 0 & 11 & 13 & 84.6 & 92.3 \\
\hline 2. Mangrove & 0 & 9 & 4 & 0 & 0 & 0 & 1 & 0 & 0 & 9 & 14 & 64.3 & 92.9 \\
\hline 3. Mill & 4 & 1 & 3 & 2 & 2 & 0 & 2 & 0 & 0 & 3 & 14 & 21.4 & 42.9 \\
\hline 4. Hayes & 2 & 2 & 1 & 8 & 0 & 0 & 0 & 0 & 0 & 8 & 13 & 61.5 & 69.2 \\
\hline 5. Wildcat & 0 & 0 & 0 & 3 & 10 & 0 & 1 & 0 & 0 & 10 & 14 & 71.4 & 92.0 \\
\hline 6. Bolster & 0 & 2 & 1 & 1 & 0 & 6 & 1 & 1 & 2 & 6 & 14 & 42.9 & 50.0 \\
\hline 7. Curiosity & 1 & 2 & 0 & 0 & 0 & 2 & 9 & 0 & 0 & 9 & 14 & 64.3 & 78.6 \\
\hline 8. Dead End & 2 & 0 & 1 & 0 & 0 & 1 & 0 & 7 & 2 & 7 & 13 & 53.8 & 69.2 \\
\hline 9. Tarzan & 0 & 0 & 1 & 0 & 0 & 2 & 1 & 3 & 7 & 7 & 14 & 50.0 & 71.4 \\
\hline Overall & & & & & & & & Perm & utation & $\begin{array}{c}70 \\
\chi^{2} \\
\text { est trace }\end{array}$ & $\begin{array}{c}123 \\
\% \text { chan } \\
=264.5 \\
\text { statistic }\end{array}$ & $\begin{array}{c}56.9 \\
\text { nce station } \\
5, \mathrm{df}=8, \mathrm{p} \\
\mathrm{C}=1.71, \mathrm{p}\end{array}$ & $\begin{aligned} & 73.2 \\
-1 & =11 \% \\
< & 0.0001 \\
< & 0.0001\end{aligned}$ \\
\hline
\end{tabular}


Table 4. Summaries of cross-validation results derived from canonical analysis of principal coordinates (CAP) in alternative tests attempting to obtain better allocation success rates by pooling stations into mega-groups: (a) the 3-region model based on 11 variables; and (b) the habitat comparison model based on 6 variables. For comparison purposes we also include the results of the models based on (c) off-by-one and (d) 9-stations as fully presented in Table 3. Station numbers as in Fig. 1

\begin{tabular}{|c|c|c|c|c|c|c|c|c|c|c|c|c|c|c|c|c|}
\hline $\begin{array}{l}\text { Grouping } \\
\text { alternatives: } \\
\text { mega-groups }\end{array}$ & $\begin{array}{c}\text { Categories: } \\
\text { stations } \\
\text { included }\end{array}$ & $\delta^{13} \mathrm{C}$ & $\mathrm{Li}$ & $\mathrm{Na}$ & $\overline{\mathrm{Mg}}$ & $\begin{array}{l}\text { Vari } \\
\mathrm{Cr}\end{array}$ & $\begin{array}{l}\text { iables } \\
\text { Mn }\end{array}$ & $\begin{array}{l}\text { S sele } \\
\text { Co }\end{array}$ & $\begin{array}{l}\text { ected } \\
\text { Zn }\end{array}$ & $\mathrm{d}-$ & $\mathrm{Rb}$ & $\mathrm{Sr}$ & $\mathrm{Y}$ & $\overline{\mathrm{Ba}}$ & $\%$ correct & $\begin{array}{c}\% \text { correct } \\
\text { overall }\end{array}$ \\
\hline (a) Region & $\begin{array}{c}\text { Down: } 1,2 \\
\text { Mid: } 3,4,5,6 \\
\text { Up: } 7,8,9\end{array}$ & & $*$ & & * & * & * & * & * & * & * & $*$ & $*$ & * & $\begin{array}{c}\text { Down }=70 \\
\text { Mid }=49 \\
U p=76\end{array}$ & 62.6 \\
\hline $\begin{array}{l}\text { (b) Habitat } \\
\text { comparison }\end{array}$ & $\begin{array}{c}\text { Bayou }=2,3,4,6,8 \\
\text { Creek = 1, 5, 7, } 9\end{array}$ & & & $*$ & & & * & $*$ & & & * & $*$ & & * & $\begin{array}{l}\text { Bayou }=62 \\
\text { Creek }=64\end{array}$ & 62.6 \\
\hline (c) Off-by-one & $\begin{array}{c}9 \text { stations }+ \\
\text { neighbors }\end{array}$ & * & & $*$ & & & * & * & & & * & $*$ & & * & $\begin{array}{c}\text { See Table } 3 \\
43-93\end{array}$ & 73.2 \\
\hline (d) Stations & 9 stations & * & & $*$ & & & * & * & & & * & $*$ & & * & $\begin{array}{c}\text { See Table } 3 \\
21-85\end{array}$ & 56.9 \\
\hline
\end{tabular}

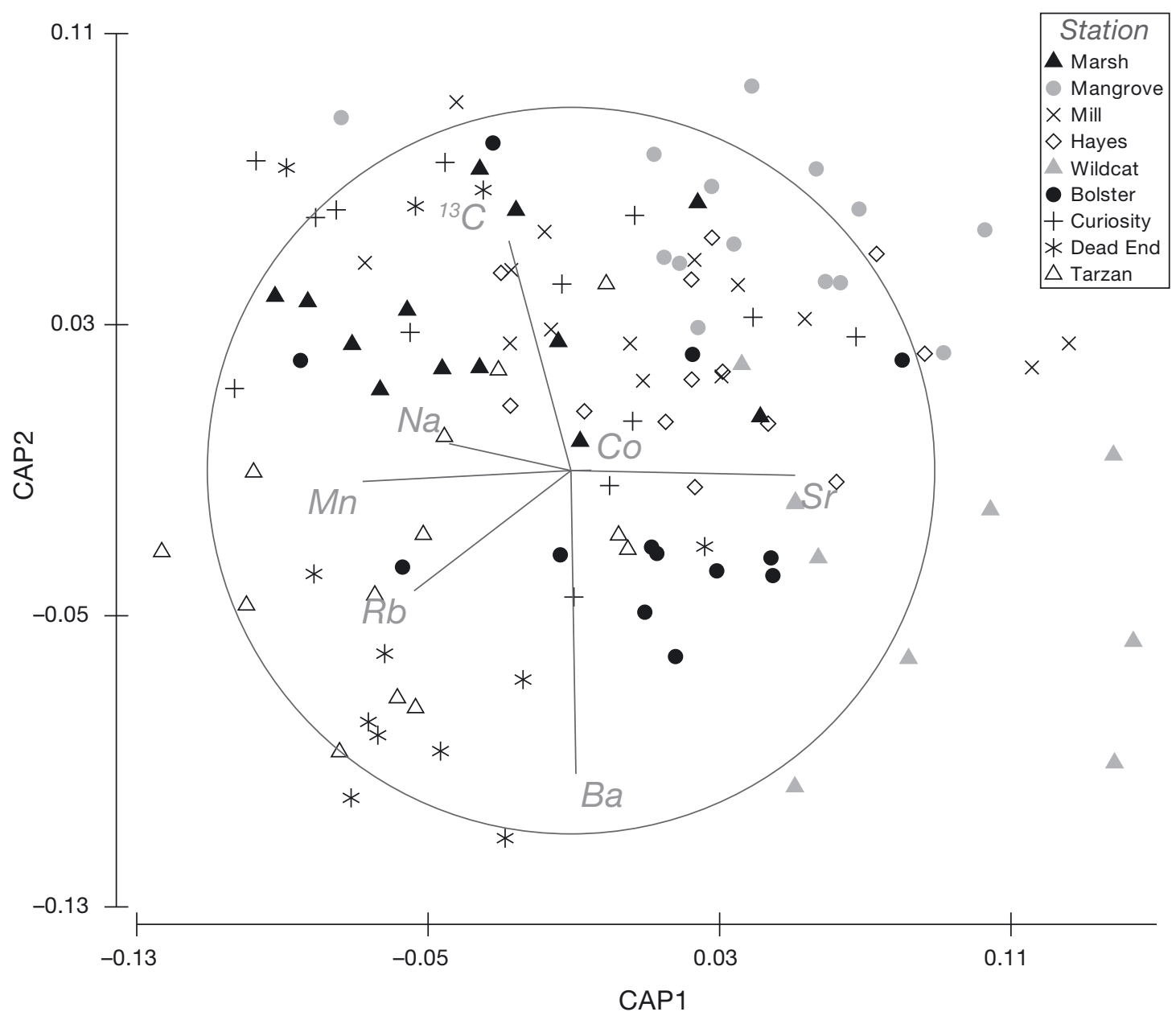

Fig. 3. Canonical analysis of principal coordinates (CAP) plot for young-of-the-year (YOY) common snook samples ( $\mathrm{n}=123$ ). Bi-plot of the first 2 CAP axes. Vectors (straight lines) sized and situated according to Pearson correlations between CAP axis scores and individual variables: ${ }^{\delta 13} \mathrm{C}, \mathrm{Na}, \mathrm{Mn}, \mathrm{Co}, \mathrm{Ba}, \mathrm{Rb}$ and $\mathrm{Sr}$ (see Table $\mathrm{S} 1 \mathrm{c}$ in the Supplement) 
fied: $84.6 \%$; Table 3) appear in the upper left quadrant of the CAP plot. Similarly, most of the Mangrove samples $(64.3 \%$ correct) grouped together in the upper right quadrant. Samples from Mill, while widely dispersed (only $21.4 \%$ correctly classified) all occur in the upper portion of the CAP plot. Because the $\delta^{13} \mathrm{C}$ vector was strongly correlated (Pearson's $r=0.63$ ) with CAP2 and aligned almost directly upwards, the resultant overlay illustrates how this otolith microchemical component influenced patterns in the cloud of sample points; i.e. snook in Mangrove, Marsh, and Mill, with consistently high concentrations of $\delta^{13} \mathrm{C}$, appear in the upper half the CAP plot (see also Fig. 2a, Table S1c in the Supplement). In contrast, the vector representing Ba aligned almost directly downward (CAP2: $\mathrm{r}=$ -0.83 ), and was associated with samples from Wildcat, Bolster, Curiosity, Dead End, and Tarzan (see also Fig. 2g). Mn and Rb were well-correlated with CAP1 (Pearson's $r=-0.57$ and -0.43 , respectively), as was $\mathrm{Sr}$ but aligned in the opposite direction $(\mathrm{r}=0.62)$. The other 2 chemical constituents, $\mathrm{Na}$, and $\mathrm{Co}$, were less influential (as indicated by the shorter vector lengths).

\section{Contribution rates}

Applying the CAP routine, each of the 40 yr-1 snook was assigned to the station whose centroid was closest to it in multivariate space (Table 5, col- umn 1). The centroid-to-sample analysis indicated that one yr-1 sample was 3 times farther from its assigned station centroid than the average for all other stations (near Marsh: Fish ID 40); this sample was eliminated from further analyses.

Based on the swimming distances $(\mathrm{km})$ between assigned nursery stations and the actual yr-1 collection sites, only one of the yr-1 snook remained close to the station it had occupied as a YOY recruit (i.e. Fish ID 19 moved only $0.4 \mathrm{~km}$ ). A wide dispersal range was displayed overall, with the great majority of juvenile snook $(70 \%)$ moving $2-10 \mathrm{~km}$ at some time between their early YOY and yr-1 stage.

Wildcat was assigned the greatest number $(n=10)$ of yr-1 snook, representing $26 \%$ of the yr-1 samples (i.e. 0.26 per the Dahlgren index). Wildcat also had the highest area-standardized contribution rate $($ Beck index $=40.7)$ (Table 5). Overall, 3 of the stations, Wildcat, Dead End, and Curiosity, were markedly superior in contribution rates and met the criteria for being defined as a nursery under the Beck and Dahlgren definitions (i.e. greater than the overall average). For the simple proportional approach (Dahlgren index; Dahlgren et al. 2006), one additional station made an above-average nursery contribution: Hayes. In contrast, nursery contributions from the 3 stations farthest downstream were relatively low (i.e. Mangrove, Marsh, and Mill). The chisquared analysis detected that both the raw number

Table 5. Yr-1 common snook allocations and nursery contribution rates in the Little Manatee River (LMR) study area. Stations ranked highest by the Dahlgren and Beck Indices are indicated in column (8). Station names in bold font indicate 'nurseries' as defined by both indices. Chi-squared calculations compared the number of samples observed vs. number expected per station. CAP: canonical analysis of principal coordinates. Column (2) displays values derived using the Dahlgren Index (Dahlgren et al. 2006). Columns (3)-(7) display steps in the shoreline-length-standardized approach (Beck et al. 2001)

\begin{tabular}{|c|c|c|c|c|c|c|c|c|}
\hline Station & $\begin{array}{l}\text { (1) No. } \\
\text { snook } \\
\text { allocated } \\
\text { by CAP }\end{array}$ & $\begin{array}{l}\text { (2) Pro- } \\
\text { portion } \\
\text { allocated } \\
\text { by station }\end{array}$ & $\begin{array}{l}\text { (3) Shore- } \\
\text { line length } \\
\text { as proxy } \\
\text { for amount } \\
\text { of nursery } \\
\text { habitat }\end{array}$ & $\begin{array}{l}\text { (4) Pro- } \\
\text { portion of } \\
\text { total nursery } \\
\text { shoreline } \\
\text { available in } \\
\text { LMR }^{\mathrm{b}}\end{array}$ & $\begin{array}{l}\text { (5) Stan- } \\
\text { dardized } \\
\text { nursery } \\
\text { contribution } \\
\text { of each } \\
\text { station }^{\mathrm{a}}\end{array}$ & $\begin{array}{c}\text { (6) Rank } \\
\text { based on } \\
\text { Dahlgren } \\
\text { Index }\end{array}$ & $\begin{array}{l}\text { (7) Rank } \\
\text { based } \\
\text { on Beck } \\
\text { Index }\end{array}$ & $\begin{array}{l}\text { (8) Stations } \\
\text { ranked } \\
\text { highest by } \\
\text { both Indices }\end{array}$ \\
\hline 1. Marsh & 1 & 0.03 & 11.9 & 0.29 & 0.9 & 9 & 9 & \\
\hline 2. Mangrove & 2 & 0.05 & 5.2 & 0.13 & 4.1 & 8 & 7 & \\
\hline 3. Mill & 2 & 0.05 & 6.6 & 0.16 & 3.2 & 7 & 8 & \\
\hline 4. Hayes & 5 & 0.13 & 4.3 & 0.10 & 12.3 & 4 & 4 & \\
\hline 5. Wildcat & 10 & 0.26 & 2.6 & 0.06 & 40.7 & 1 & 1 & First \\
\hline 6. Bolster & 3 & 0.08 & 3.0 & 0.07 & 10.6 & 6 & 6 & \\
\hline 7. Curiosity & 6 & 0.15 & 2.5 & 0.06 & 25.4 & 3 & 3 & Third \\
\hline 8. Dead End & 7 & 0.18 & 2.2 & 0.05 & 33.7 & 2 & 2 & Second \\
\hline 9. Tarzan & 3 & 0.08 & 3.0 & 0.07 & 10.6 & 5 & 5 & \\
\hline $\begin{array}{l}\text { Overall } \\
\qquad \mathrm{df}=\end{array}$ & $\begin{array}{c}\text { avg. }=4.3 \\
\chi^{2}=15.7 \\
=8, \mathrm{p}=0.0\end{array}$ & $\begin{array}{l}\text { avg. }=0.11 \\
470\end{array}$ & Total $=41.3$ & 1.00 & $\begin{array}{c}\text { avg. }=15.7 \\
\chi^{2}=50.8 \\
\mathrm{df}=8, \mathrm{p}<0.0001\end{array}$ & & & \\
\hline
\end{tabular}


allocated (column 1) and area-standardized proportions (column 5) differed significantly from equivalence among the stations ( $\left.\mathrm{n}=4.3, \chi^{2}, \mathrm{p}<0.05\right)$.

\section{Nursery function analysis}

The exploratory analysis of nursery function was focused on discovering key underlying processes that may have influenced variation in the contribution rates. As a group, the ecological set explained only a moderate amount (36\%) of the variability in relative contribution rates among the stations (Table 6a). Individually, however, some of the 4 variables in this set suggested unexpected-but notable - relationships. For example, although moderate $(r=-0.38)$, the correlation between density of 40-59 mm snook versus Beck contribution rate was negative, suggesting that this factor was inversely related to contribution rate. In fact, Mill, which had one of the lowest contribution rates (Beck index $=$
3.2), had one of the highest densities of YOY snook (ranking first among the 9 stations at 28 per $100 \mathrm{~m}^{2}$ (Fig. 4d, Table S2 in the Supplement). Additionally, the correlation between contribution rate and YOY condition was unexpectedly moderate and not significant $(\mathrm{r}=0.34)$. For example, Wildcat scored very high in contribution rate (Beck index $=40.7$ ) but YOY snook netted at that station were in somewhat low condition $\left(R_{W}=-4.0\right)$ (Fig. 4c, Table S2).

The physicochemical set explained a substantial amount $(73 \%)$ of the variation in contribution rate among the stations (Table 6b). The most significant correlate was salinity $(\mathrm{r}=-0.76, \mathrm{p}<0.05)$ indicating that greater nursery contribution rates were associated with stations such as Wildcat, Dead End, and Curiosity which had lower salinity levels (0.31.4 psu; Fig. 4e, Table S2). The second highest correlate was distance to the estuary mouth, with greater contribution from more remote stations (9.4-13.6 km from the mouth; $\mathrm{r}=0.70, \mathrm{p}<0.05)$ (Fig. 4b).

Table 6. Factors associated with nursery contribution rates (Beck Index) by station (n = 9). A set-based analysis was used to assess the degree to which ancillary variables measured at young-of-the-year (YOY) common snook sampling locations (autumn 2013) influenced nursery contribution rates (Table 5). Column (1): sets used to group the explanatory variables for analysis and multiple regression results using all variables in the set; column (2): lists variables in each set; column (3): Pearson correlation values derived for each variable vs. contribution rate. In columns (2) and (3), variables having significant Pearson correlations $(p<0.05)$ are shown in bold. Column $(4)$ gives the significant multiple linear regression model based on the combination of explanatory variables that best explained (greatest $\mathrm{r}^{2}$ ) variation in the Beck contribution index among the stations. Beck contribution was square-root transformed and explanatory variables were normalized for the analyses. rkm: riverkilometer; na: not applicable

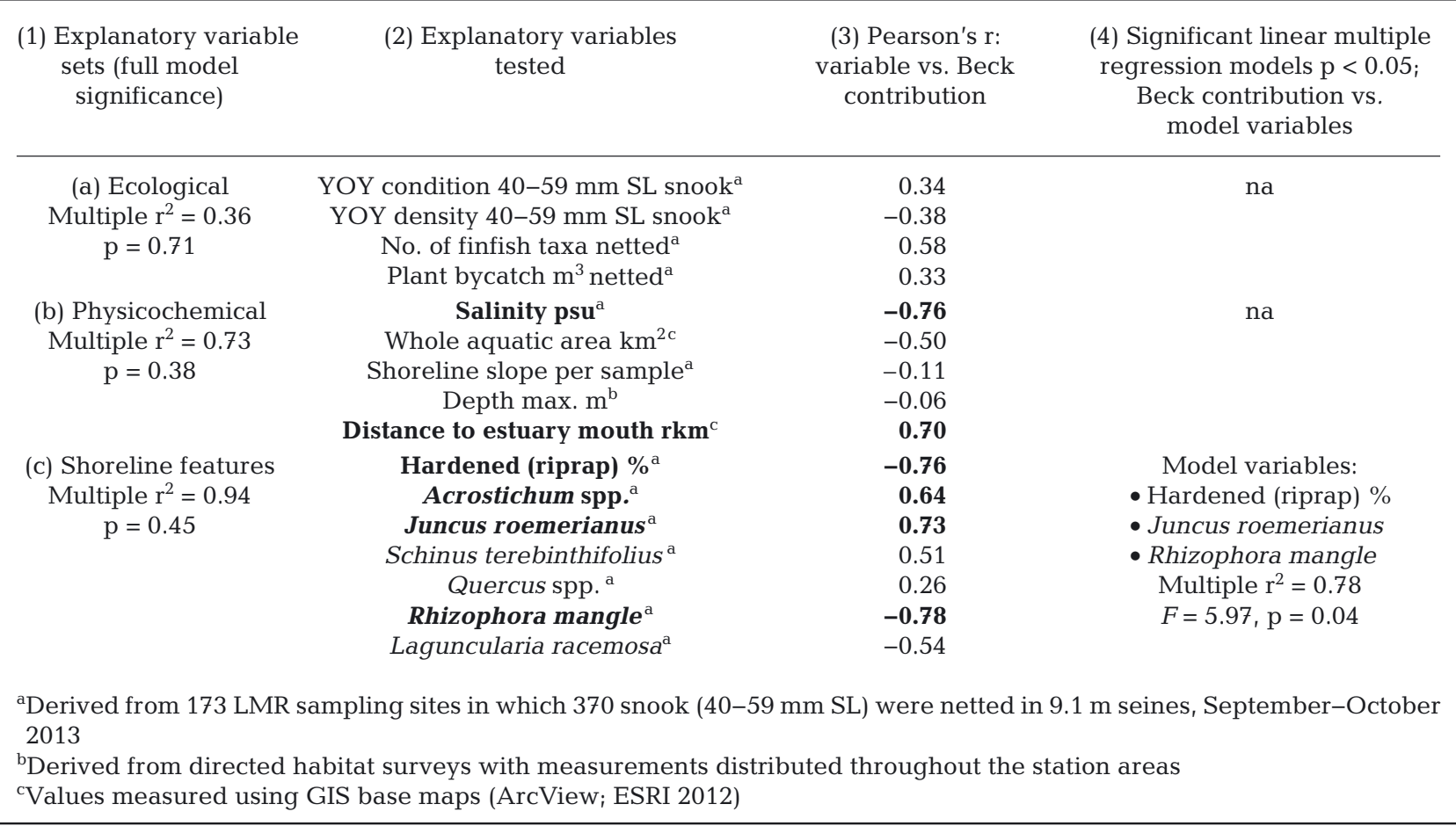


a) Nursery contribution

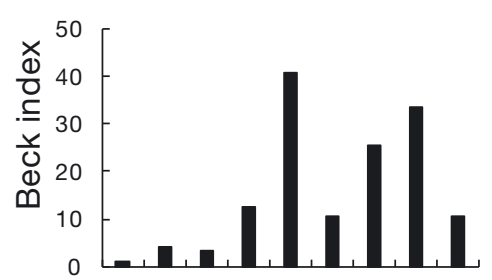

c) Fish (YOY) condition

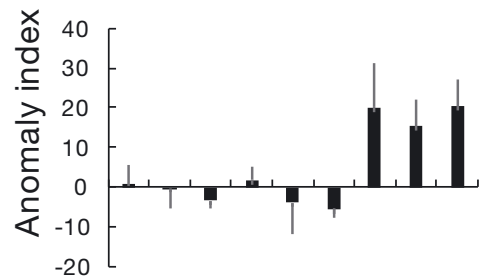

e) Salinity

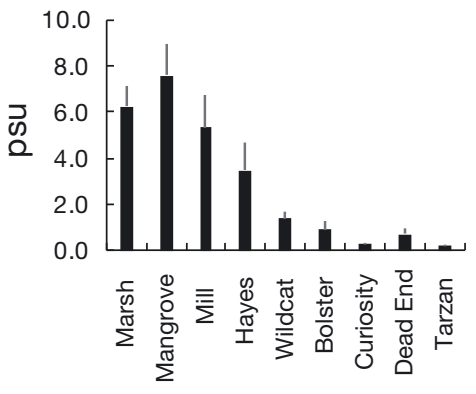

b) Distance to mouth

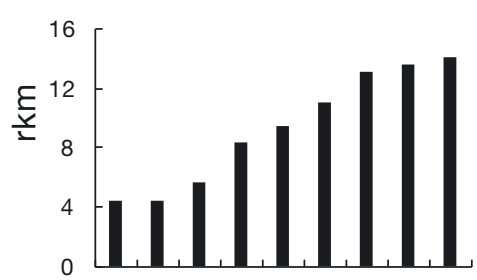

d) YOY density

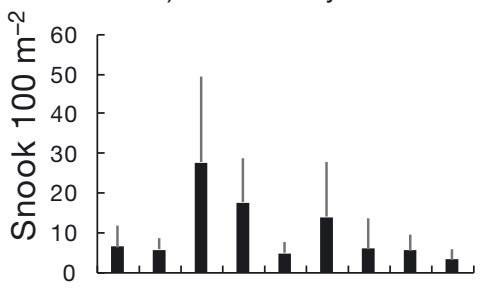

f) Station area

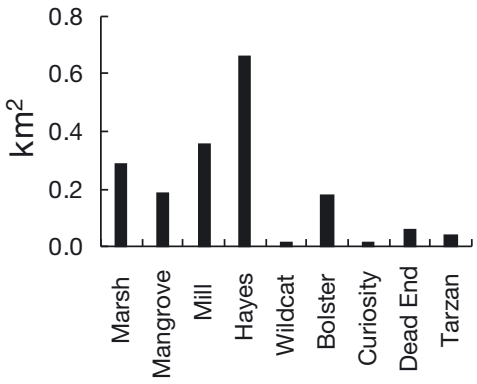

ment). Although most riprap shorelines had grasses and mangrove vegetation growing in gaps within the rocky material (Fig. S2a), overall, expansive shoreline hardening was associated with reduced relative contribution rates. The exotic shrub Schinus terebinthifolius has intensively invaded habitats in most of the stations (average 15\% of the sites; Fig. 5d); nevertheless, contribution values of such shorelines remained relatively high ( $\mathrm{r}=$ 0.51). A significant multiple regression model explaining $78 \%$ of the variation in contribution rates among the stations had 3 shoreline features (Table 6, Fig. 6):

$$
\begin{gathered}
(\text { Beck })^{-2}=3.55+0.50 \times \text { Hardened }+ \\
1.24 \times \text { Juncus }-1.18 \times \text { Rhizophora }
\end{gathered}
$$

where Beck is the area-standardized nursery index, 'hardened' is the proportion of sampling sites with concrete or wooden reinforced shorelines, 'Juncus' is the proportion of sampling sites with Juncus roemerianus, and Rhizophora is the proportion of sampling sites with Rhizophora mangle.

\section{DISCUSSION}

(a) Contribution (Beck index Table 5); (b) river-kilometers from station midpoint to Little Manatee River (LMR) mouth (at Tropical Isle); (c) condition index derived from 370 youngof-the-year (YOY) common snook (40-59 mm SL); (d) density of 370 YOY snook (40-59 mm SL); (e) salinity (mid-water) psu; (f) open aquatic surface area for each station using boundaries as shown in Fig. 1

By far the most influential set, shoreline features, explained $94 \%$ of the variation in nursery contribution rates (Table 6c). The analysis clearly suggests that the greatest nursery contribution was from habitats with shorelines dominated by salt marsh vegetation (65$94 \%$ of the sampling sites: Acrostichum spp., $\mathrm{r}=0.64$; Juncus roemerianus, $\mathrm{r}=0.73, \mathrm{p}<0.05$ each; Fig. 5b,c, Table S2). Unexpectedly, shorelines dominated by mangroves had lower contribution rates (Fig. 5e,f; Rhizophora mangle, $\mathrm{r}=-0.78, \mathrm{p}<0.05$ and Laguncularia racemosa, $\mathrm{r}=-0.54)$. One of the most influential variables was hardened (riprap) $\%(r=-0.76)$. As such, Marsh had by far the greatest proportion of shoreline in the LMR study area (29\%), but much of this station's shoreline was comprised of hardened man-made banks (i.e. concrete or wooden seawalls), modified by riprap installations (38\% of the sampling sites; Fig. 5a and as pictured in Fig. S2a in the Supple- distinctive otolith signatures were identified for 9 potential snook nurseries (the stations) distributed along an $18 \mathrm{rkm}$ segment of a subtropical riverine estuary. Each station was separated from its nearest neighbor by an average distance of $2.7 \mathrm{~km}$ (swimming distances of 1.0 to $4.5 \mathrm{~km}$ between area midpoints), which, to our knowledge, represents one of the finest-scale applications to date of otolith microchemistry for distinction and prioritization of estuarine habitats. Using CAP and jackknifed leaveone-out classification for 123 fish, 70 (56.9\%) were classified correctly, compared with $11.1 \%$ that would have been correctly classified by chance alone $\left(\chi^{2}\right.$, $\mathrm{p}<0.0001)$. These results indicate sufficient microchemical distinction among water masses to serve as natural fish tags, representing a notable achievement in otolith microchemistry research focusing on the fine-scale characterization of aquatic areas used as nurseries by estuarine transient finfishes. 


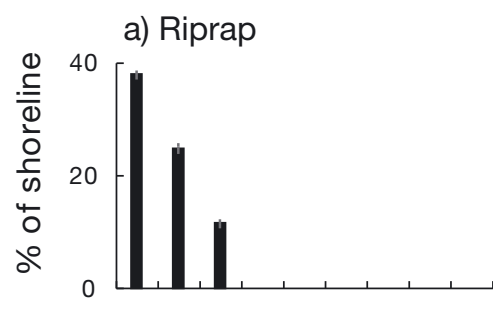

c) Juncus roemerianus

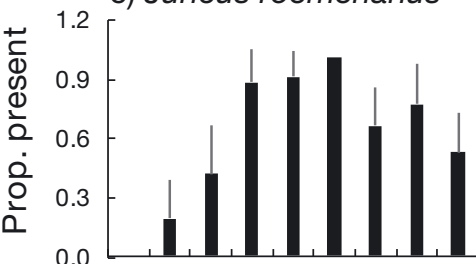

e) Rhizophora mangle

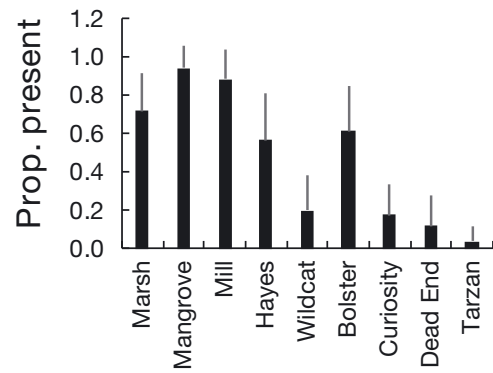

b) Acrostichum spp.

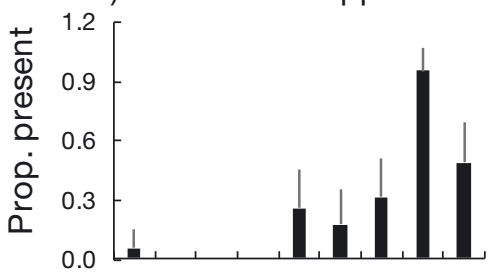

d) Schinus terebinthifolius

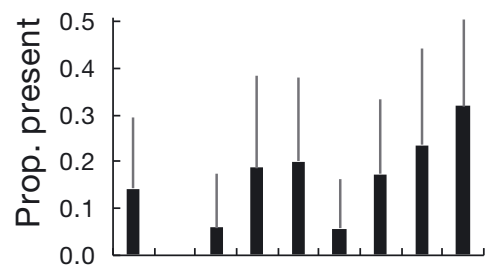

f) Laguncularia racemosa

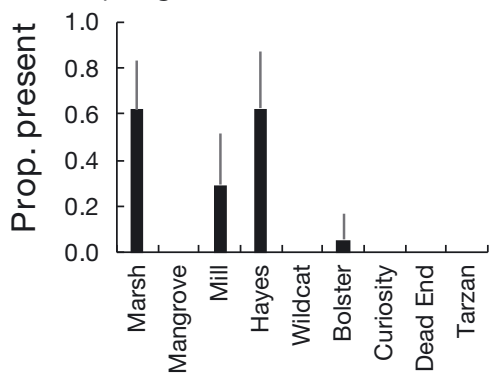

Fig. 5. Shoreline features at common snook sampling sites (173 deployments of $9.1 \mathrm{~m}$ seine in autumn 2013). (a) percent of shoreline hardened with wooden or concrete seawalls reinforced with rocky riprap material; (b-f) proportion of samples taken at each station $(n=16$ to 25$)$ in which the feature was present

Multiple regression: contribution vs. 3 shoreline features

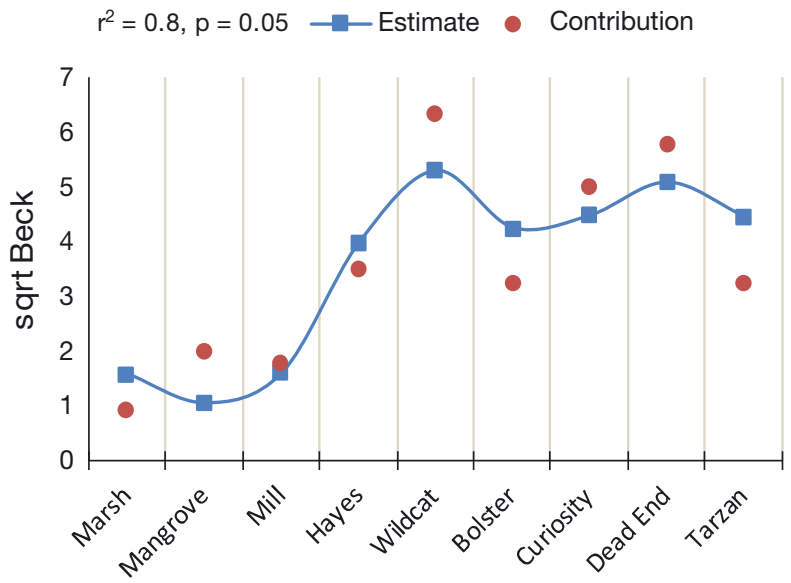

Fig. 6. Actual contribution (individual dots) and model estimate (squares linked by a smoothed line) comparison. This multiple regression model $(\mathrm{p}<0.05)$ combined 3 shoreline features as variables (Juncus roemerianus, Rhizophora mangle, hardened [riprap]) to explain $78 \%$ of the variation in contribution rate (Beck index; Table 5$)$ by station $(n=9)$ (see Table 6, column (4))
A key objective in life history applications of otolith microchemistry is to match the scale and design of the study to the overall distributional patterns and spatial habits of individuals in the fish population of interest. Designing an ontogenetic connectivity study required fine-scale knowledge about the life history of the species. For our study, we drew upon life history studies and long-term monitoring data available for juvenile snook in, or very close to, our study area (McMichael et al. 1989, Winner et al. 2010, Brame et al. 2014). This knowledge was vital in developing an appropriate approach designed to (1) characterize groups that are far enough apart to have chemically distinct water masses, (2) represent all possible contributing groups, and (3) sample over a period during which microchemical signatures remain stable (Campana 1999, 2005, Elsdon et al. 2008). These 3 criteria provide a framework for evaluating the reliability of the study results.

Addressing the first criterion, the more distinct the microchemical signatures between the potential nursery areas, the greater the associated cross-validation success values (Mercier et al. 2011). To evaluate the reliability of the $56.9 \%$ overall YOY cross-validation success rate attained in the present study, we compiled a large representative inventory of previous otolith microchemistry studies based on estuarine transient finfish (20 published papers representing 47 study components; details in Table S3 in the Supplement). Each study component represents the reported results for a single cohort of a single species. With overall crossvalidation success ranging from 29 to $97 \%$ (average $=76 \%$ ), these studies addressed 4 basic types of comparisons: between habitat types (6 components), between streams in a freshwater coastal river (1 component), between estuaries (inter-estuary: 30 components), and between areas within estuaries (intraestuary: 10 components plus the present study) (Table 7). Four scale-related features of the study designs were highlighted for the estuarine spatial comparison studies: extent, proximity, number of groups, and samples per group. Focusing on the intra-estuary spatial-comparison studies (as for our study), 'number of groups' was the only design feature significantly correlated with overall cross-validation success rate. For the intra-estuarine study components, the greater 
Table 7. Literature overview comparing 48 study components (each component composed of one cohort and one species) derived from 20 otolith microchemistry publications (plus the present study). Some papers included more than one type of design. This selection of studies was limited to analyses of estuarine and/or coastal finfish nurseries. Details of each study and citations are included in Table S3 in the Supplement. Correlations between design feature and overall cross-validation success

(Pearson's r) are given for inter- and intra-estuary design types. YOY: young-of-the-year; na: not available ${ }^{* *} \mathrm{p}<0.05$

\begin{tabular}{|c|c|c|c|c|c|c|c|}
\hline \multirow[t]{2}{*}{ Design types } & \multirow[t]{2}{*}{ Papers } & \multirow[t]{2}{*}{ Components } & \multicolumn{4}{|c|}{ Features of the design [avg. (min. - max.)] } & \multirow{2}{*}{$\begin{array}{c}\text { Overall } \\
\text { cross- } \\
\text { validation } \\
\text { success }(\%)\end{array}$} \\
\hline & & & $\begin{array}{l}\text { Extent } \\
\text { overall } \\
(\mathrm{km})\end{array}$ & $\begin{array}{l}\text { Proximity }(\mathrm{km}) \\
\text { between group } \\
\text { midpoints }\end{array}$ & $\begin{array}{l}\text { Number } \\
\text { of } \\
\text { groups }\end{array}$ & $\begin{array}{l}\text { Samples } \\
\text { per } \\
\text { group }\end{array}$ & \\
\hline $\begin{array}{c}\text { Comparison by } \\
\text { habitat type }\end{array}$ & 3 & 6 & $\begin{array}{c}293 \\
(36-500)\end{array}$ & na & $\begin{array}{c}3 \\
(2-4)\end{array}$ & $\begin{array}{c}128 \\
(15-245)\end{array}$ & $\begin{array}{c}77 \\
(66-94)\end{array}$ \\
\hline Coastal river (freshwater) & 1 & 1 & 720 & 20 & 8 & 10 & 97 \\
\hline $\begin{array}{l}\text { Inter-estuary } \\
\text { spatial comparison }\end{array}$ & 14 & 30 & $\begin{array}{c}440 \\
(6-1800) \\
r=0.15\end{array}$ & $\begin{array}{c}88 \\
(6-595) \\
r=0.18\end{array}$ & $\begin{array}{c}6 \\
(3-17) \\
r=-0.37^{* *}\end{array}$ & $\begin{array}{c}29 \\
(8-166) \\
r=0.14\end{array}$ & $\begin{array}{c}75 \\
(29-94)\end{array}$ \\
\hline $\begin{array}{l}\text { Intra-estuary } \\
\text { spatial comparison }\end{array}$ & 5 & 10 & $\begin{array}{c}80 \\
(7-169) \\
r=-0.46\end{array}$ & $\begin{array}{c}23 \\
(6-40) \\
r=-0.18\end{array}$ & $\begin{array}{c}4 \\
(2-6) \\
\mathrm{r}=-0.78^{* *}\end{array}$ & $\begin{array}{c}24 \\
(5-63) \\
r=0.45\end{array}$ & $\begin{array}{c}76 \\
(60-88)\end{array}$ \\
\hline Intra-estuary: present study & 1 & 1 & 18 & 2.7 & 9 & 14 & 56.9 \\
\hline Grand total & 21 & 48 & $\begin{array}{c}\text { avg. }=343 \\
(6-1800)\end{array}$ & $\begin{array}{c}\operatorname{avg} .=68 \\
(6-595)\end{array}$ & $\begin{array}{c}\text { avg. }=5 \\
(2-17)\end{array}$ & $\begin{array}{c}\operatorname{avg} .=40 \\
(5-245)\end{array}$ & $\begin{array}{c}\text { avg. }=76 \\
(29-94)\end{array}$ \\
\hline
\end{tabular}

the number of groups compared, the lower the overall cross-validation success $(\mathrm{r}=-0.78, \mathrm{p}<0.05$; Table 7$)$. Extrapolating the linear trend based on this relationship, the expected cross-validation success rate for 9 groups (as in the present study) would be $52 \%$ (Fig. S3 in the Supplement). Thus, at $56.9 \%$, the present study not only follows a trend set by previous intra-estuarine studies, but attained a slightly better than expected cross-validation success rate. It should also be noted that not only were the groups in our study much closer together $(2.7 \mathrm{~km}$ apart vs. $6-40 \mathrm{~km}$ apart in previous intra-estuarine studies), but the stations were also distributed along a gradient of changing habitats (mangroves downstream gradually transitioning to salt marshes farther upstream), further masking sharp distinctions between spatial areas. Thus, the magnitude of distinction in our study was moderated by the fine scale, greater number of groups, and gradient-influenced nature of the system.

Group distinction among otolith signatures is produced by differences in the component variables. Four of the otolith constituents that composed the signatures in the present study are among the top 5 constituents composing signatures in the 12 studies in our comprehensive review that used both elements and stable isotopes: $\mathrm{Ba}, \delta^{13} \mathrm{C}, \mathrm{Sr}$, and $\mathrm{Mn}$ (Table S3). Systematic and linear trends along the $\mathrm{LMR}$ riverine gradient were evident for $\mathrm{Mn}, \mathrm{Rb}$, and $\mathrm{Ba}$, with higher levels upstream. While Sr has often been used to trace salinity-related fish migration because it is higher in otoliths from fish living in higher-salinity conditions (Sturrock et al. 2012), our Sr ratios did not display such a trend. For example, for Wildcat, which had low salinity (average 1.4 psu), YOY fish otoliths were significantly more enriched in Sr than at any other station. In coastal west-central Florida, Sr pathways are influenced by groundwater from ancient marine carbonate aquifers (Odum 1951), suggesting that water masses in Wildcat, in particular, are mixed with Sr-enriched groundwater from sources in the contributing watershed. In terms of $\delta^{13} \mathrm{C}$, while dominant plant communities (Harrigan et al. 1989, Deegan \& Garritt 1997) and mixing (Brame et al. 2014) may influence $\delta^{13} \mathrm{C}$ levels in some systems, those factors do not fully explain why the isotope was significantly higher in fish collected in the 3 stations farthest downstream (Marsh, Mangrove, Mill). Since the 3 most $\delta^{13} \mathrm{C}$-enriched stations were located closest to the mouth of LMR where tidal and wind-driven water exchange occurs readily, the most reasonable explanation for these trends may be a shift in food resources at the base of the food chain there. In fact, nearer Tampa Bay, food resources consumed by small fish tend to be more $\delta^{13} \mathrm{C}$-enriched (Malkin 2010). Clearly, the characterization of spatial groups is a function of both the distance between groups and complex factors (e.g. mixing, import) that influence the chemical composition of the water mass in which each fish subpopulation lives (Reis-Santos et al. 2018). 
Considering the second criterion, a measure of how adequately our design sampled all contributing groups is the percent of yr-1 samples reliably allocated to their presumed YOY nursery. Relatively few intra-estuarine studies have attempted to match subadults to their nursery of origin (Table S3), but in Puget Sound Chittaro et al. (2009) matched $55 \%$ of 107 yr-1 English sole $(2005,2006$ cohorts) to 1 of 5 nursery regions, suggesting that not all potential sources had been sampled. In contrast, Walther et al. (2008) matched 73 out of 78 adult American shad back to 1 of 2 nursery tributaries within the York River estuary system (eastern USA). Thus, for our study which traced $98 \%$ of yr-1 snook back to 9 nurseries, the study design covered sufficient area to include the majority of the potential nursery areas.

Finally, as indicated by the multivariate PERMANOVA results, temporal variation during the study period was not a significant factor. The 2 mo window during which YOY snook were sampled encompassed a period when microchemical signatures remained quite stable. The September-October time frame is the peak of the normal hot rainy season in Tampa Bay but the presumably continuous inflow of freshwater to the LMR did not overwhelmingly lead to short-term temporal variation among the water masses associated with the stations.

Thus, the fine-scale design proved successful in tracking juvenile snook behavior in this tributary to Tampa Bay. Accordingly, we were able to (1) detect distinct water-masses among groups separated by an average of only $2.7 \mathrm{rkm}$, (2) represent most nursery areas contributing to the yr-1 age class in the study area, and (3) limit sampling to a period in which the chemistry of the water mass remained stable. The present investigation represents the first application of otolith microchemistry at this fine scale, providing a basis for similar studies in Tampa Bay tributaries and in other estuarine systems worldwide. To improve the moderate cross-validation success rate, larger sample sizes are recommended (i.e. at least 40 YOY individuals per nursery group with at least 63 ind. in the subadult/adult group; Tables 7 \& S3). In addition, otolith signatures may vary from year to year for a given species in a particular nursery area (e.g. Clarke et al. 2009, Rakocinski et al. 2015), suggesting that replication for more than one cohort is required. In fact, in Puget Sound, markedly different spatial patterns in fish nursery contribution values occurred between 2 consecutive cohorts (Chittaro et al. 2009). Snook recruitment trends suggest that lowsalinity conditions benefit survival in nursery habitats (Ley et al. 2010). Dramatic variation in autumn salinity conditions has been observed over the $20 \mathrm{yr}$ monitoring record available for the LMR study area, with the present study representing a relatively lowsalinity year (FWRI, FIM program). The prime nurseries identified in the present study may change under different rainfall and hydrological conditions, or if, for example, a drought or hurricane were to impact the area.

\section{Contribution analysis}

Based on the area-standardized approach (Beck index; Beck et al. 2001), 3 stations - Wildcat, Dead End, and Curiosity - contributed disproportionally large (above-average) numbers of survivors to the yr-1 age class. To our knowledge, the present study is 1 of only 5 published papers focused on estuarine transient finfish that ranked nursery areas based on otolith microchemistry by applying contribution analysis on a spatially explicit basis (Table S3). Here, we have not considered the less-comparable studies that ranked nursery areas based on habitat type (e.g. seagrass beds vs. mangroves; Mateo et al. 2010) (Table S3). Although not part of the present study, it is useful to note that for the studies in which cohorts of the same species in the same areas were compared between 2 years, each year displayed different trends in nursery contribution (Chittaro et al. 2009, ReisSantos et al. 2013, Tanner et al. 2013). Considering only the more widely applied Dahlgren et al. (2006) approach, we compared our results (4 above-average nurseries out of 9 stations or $44 \%$ ) to 11 other published examples of single cohort analysis (i.e. components in Table S3). Including the present study, an average of $40 \%$ of the groups surveyed were identified as important nurseries (Chittaro et al. 2009, 44 and $60 \%$; Vasconcelos et al. 2011, 50\%; Tanner et al. 2013, 33-67 \%; Reis-Santos et al. 2013, 20-40\%). The contribution analysis approach provides an objective basis for prioritizing nurseries on a spatially specific basis, but caution should be used until more than one cohort has been subjected to the analysis under a range of circumstances.

\section{Nursery function analysis}

Analyzing factors influencing survival during the transition between juvenile and adult phases in the life of an estuarine transient finfish may lead to a better understanding of variation in nursery contribution rates among estuaries, among sites within estuaries, 
or over time (Vasconcelos et al. 2011). Among the several studies in which the otolith microchemistry has been applied in estuarine environments, to our knowledge, only Chittaro et al. (2009) and Vasconcelos et al. (2011) attempted to quantify relationships between contribution rates and a suite of potentially influential extrinsic factors on a spatially explicit basis. Spatial patterns in contribution rates among 5 regions for 2 cohorts within Puget Sound, however, were not significantly explained by the 6 ancillary variables tested (i.e. juvenile density, habitat area, rainfall, dissolved oxygen, $\mathrm{pH}$, temperature; Chittaro et al. 2009). Similarly, juvenile density, habitat area, juvenile abundance, and condition displayed no significant correlations with contribution rates for 5 species in 3-5 estuaries in Portugal (Vasconcelos et al. 2011). Increasing the number of spatial groups (e.g. $>5$ areas) to allow more robust statistical analysis was recommended for future studies attempting to explain the underlying causes of variation in nursery function that might lead to variation in contribution of juveniles to subsequent age classes (Vasconcelos et al. 2011). In fact, the present analysis, which compared nursery function among 9 areas in a single estuary, did find significant relationships between contribution rate and certain ancillary variables (i.e. - salinity, + distance-to-mouth, - hardened shoreline, + Acrostichum spp., + Juncus roemerianus, Rhizophora mangle), as discussed below.

The nursery function analysis developed in the current study analyzed potential relationships between nursery success (i.e. contribution rates from 9 distinct nursery locations) and 16 explanatory variables within a 3-set framework (i.e. ecological, physicochemical, shoreline features). To select and analyze the relationships, we drew upon decades of foundational research into why and how estuaries support transient finfish juveniles that maintain some of the world's most valuable coastal fisheries (e.g. McHugh 1967, Day et al. 1989, Valiela 1995, Connell \& Gillanders 2007, Nagelkerken 2009, Whitfield 2017). The stimulating element offered by modern otolith microchemistry to this body of research is that instead of relying on indirect measures of nursery success (e.g. juvenile density on the nursery grounds), we now have a way of directly measuring juvenile contribution from specific locations to subsequent age groups (Vasconcelos et al. 2011). A wider body of knowledge is required, however, to understand the details of design and application relative to this valuable tool.

None of the 4 ecological variables tested explained a significant amount of the variation in contribution rate among the stations (i.e. condition, density, diver- sity, submersed plant material). Perhaps most surprisingly, like the findings of previous investigators, the LMR stations that made the greatest contribution of juveniles to the subsequent age class of the cohort did not have the greatest YOY snook densities (Chittaro et al. 2009, Vasconcelos et al. 2011). In fact, the overall trend was negative, indicating that at some level of YOY snook density, crowding and associated competition for limited resources were detrimental to survival (Adams \& Wolfe 2006, Brennan et al. 2008). Clearly, as recognized historically, the relationship between nursery ground density and survival of juveniles is more complex than a linear relationship would express. Our results suggest that juvenile density may have been too low in some stations to support high contribution rates (e.g. Mangrove and Marsh) but high enough in other stations (e.g. Mill, Bolster) to induce significant juvenile mortality. These trends generate a hump-shaped survival-abundance curve, exemplifying Allee and density-dependent effects on recruitment (Valiela 1995). The same processes probably explain why the relationship between contribution and condition of YOY snook, although moderately positive, was not statistically significant. Vasconcelos et al. (2011) likewise found that juvenile condition was not related to observed contribution to adult populations. Overall, modeling the linkages between ecological factors and nursery success is extremely complex, incorporating trophic interactions, productivity, and larval processes (Adams et al. 2006). Otolith microchemistry analysis should be incorporated in future attempts to fully characterize ecological processes influencing finfish survival as they make ontogenetic habitat shifts (e.g. longterm monitoring programs).

In terms of physicochemical variables, the 3 tributaries with highest contribution rates-Wildcat, Curiosity, and Dead End - were located far from the estuary mouth, reflecting the possibility that survival was enhanced where stenohaline marine predators (e.g. Carangidae) were less likely to make occasional foraging trips. In addition, oligohaline (0.5-1.5 psu) conditions that prevailed in these locations during the wet season of the study period may limit entry of the same guild of marine predators during the peak recruitment season (autumn) for early YOY snook (Stevens et al. 2013). Remoteness and low salinity have historically been considered attributes of estuarine nursery grounds, thought to coincide with behavioral mechanisms attracting young fish to locations with these features (Day et al. 1989). Thus, it may not be surprising that these 2 variables - low salinity and far distance from the mouth-were 
strong and significant correlates with nursery contribution rates, signaling important features of prime nursery locations in the LMR.

The third set explored-shoreline features - included the variables that were most influential on nursery contribution rates at the fine scale analyzed in our study. First, reduced shoreline vegetation due to installation of extensive, artificially hardened banks led to less cover for juvenile snook from predators throughout Marsh, and parts of Mangrove and Mill. Even though some of the negative effects of extensive hardened banks reinforced with riprap were probably mitigated by recruitment of wetland plants among the looser material in some places, detrimental impacts were not fully offset. Second, early YOY snook were more likely to survive to the yr-1 stage in the locations dominated by salt marsh plants - chiefly and significantly along shorelines composed of Acrostichum spp. and J. roemerianus. The influence of salt marsh habitat peaked in Wildcat, where the creek's shorelines were actually the margins of expansive intertidal areas with hydrologically complex networks of small creeks draining the Juncus-dominated habitat (Fig. S2e). The edges of tidal salt marshes are an important habitat for many juvenile fishes (Halpin 2000). In contrast, mangrove shorelines had lower nursery contribution rates for small YOY snook (40-60 mm SL); mangroves, however, may be more advantageous as nurseries for later-stage snook juveniles (>100 mm SL) (e.g. Barbour et al. 2014). Structurally complex intertidal habitats such as salt marshes and mangroves provide refuge for juvenile fish, but at low tide almost all fish are forced into creeks and channels (e.g. the main channel of Wildcat) where larger piscivorous fish may be present (Whitfield 2017), unless they have been excluded by incompatible salinities or remoteness as described above. These scenarios highlight the importance of maintaining aquatic connectivity for (1) small-scale, tidally driven movements (e.g. marsh-to-creek), and (2) large-scale, ontogenically driven movements (e.g. along the gradient from mangrove- to salt marsh-dominated habitats). It should be noted that, while abundance peaks in Florida, the distributional range of snook also encompasses regions where salt marsh habitats do not exist or are rare (Rivas 1986). For example, juvenile snook occupy freshwater and low salinity backwater habitats composed of mangroves, cattails, water hyacinths, and bamboo in Puerto Rico (Aliaume et al. 1997, 2000). Our own observations indicate that almost any oligohaline pond, creek, or ditch can at least temporarily support juvenile snook recruits; the results of the present study, however, indicate that survival to yr-1 is more probable in aquatic systems where extensive salt marsh ecosystems are present.

We recommend continued refinement of tools such as otolith microchemistry which can be used to directly identify and prioritize habitats that effectively sustain fish populations. Only by understanding which habitat locations and features best help support a population during good times as well as bad, can the most consequential tracts of fish habitat be highlighted for conservation action. Furthermore, under a spatially based fisheries management regime, locations with high nursery contribution rates can be incorporated into a network of protected areas so that fish productivity and biodiversity in estuarine systems may be optimized to protect valuable estuarine fisheries for current and future generations.

Acknowledgements. This paper is dedicated to the memory of our esteemed colleague, Dr. David L. Jones. The Tampa Bay Environmental Fund funded this study, through the National Fish and Wildlife Foundation (NFWF) (Project number 1802.13.036679/36679, 'Determining Which Tidal Tributaries Are the Best Snook Nurseries'), with additional support from the Florida Fish and Wildlife Conservation Commission. Otolith processing was facilitated by the College of Marine Science at the University of South Florida (St. Petersburg). We especially thank Marti J. Anderson for her invaluable help in implementing PERMANOVA analyses, as well as a range of other aspects of the study. We thank F. X. Courtney, C. C. McIvor, P. W. Stevens, E. B. Peebles and R. G. Taylor for extensive input in project design and implementation. We greatly appreciate the help of A. A. Trotter, D. O. Westmark, C. M. Gardinal and the entire staff of the Florida Fish and Wildlife Research Institute Age and Growth Laboratory (FWRI, St. Petersburg). We also thank C. P. Shea (FWRI, St. Petersburg) for advising our team on statistical analyses.

\section{LITERATURE CITED}

Adams AJ, Wolfe RK (2006) Cannibalism of juveniles by adult common snook (Centropomus undecimalis). Gulf Mex Sci 24:11-13

Adams AJ, Dahlgren CP, Kellison GT, Kendall MS and others (2006) Nursery function of tropical back-reef systems. Mar Ecol Prog Ser 318:287-301

Akaike H (1973) Information theory as an extension of the maximum likelihood principle. In Petrov BN, Caski F (eds) Proc $2^{\text {nd }}$ Int Symp on Information Theory. Akademiai Kiado, Budapest, p 267-281

Aliaume C, Zerbi A, Miller JM (1997) Nursery habitat and diet of juvenile Centropomus species in Puerto Rico estuaries. Gulf Mex Sci 15:77-87

Aliaume C, Zerbi A, Joyeux JC, Miller JM (2000) Growth of juvenile Centropomus undecimalis in a tropical island. Environ Biol Fishes 59:299-308

Anderson MJ (2001) A new method for non-parametric multivariate analysis of variance. Austral Ecol 26:32-46 
Anderson MJ, Gribble NA (1998) Partitioning the variation among spatial, temporal and environmental components in a multivariate data set. Aust J Ecol 23:158-167

Anderson MJ, Robinson J (2003) Generalized discriminant analysis based on distances. Aust N Z J Stat 45:301-318

Anderson MJ, Willis TJ (2003) Canonical analysis of principal coordinates: a useful method of constrained ordination for ecology. Ecology 84:511-525

Anderson MJ, Gorley RN, Clarke KR (2008) PERMANOVA+ for PRIMER: guide to software and statistical methods. Plymouth Marine Laboratory, Plymouth

* Barbour AB, Adams AJ, Lorenzen K (2014) Size-based, seasonal, and multidirectional movements of an estuarine fish species in a habitat mosaic. Mar Ecol Prog Ser 507: 263-276

Beck MW, Heck KL Jr, Able KW, Childers DL and others (2001) The identification, conservation, and management of estuarine and marine nurseries for fish and invertebrates. Bioscience 51:633-641

Blewett DA, Stevens PW, Carter J (2017) Ecological effects of river flooding on abundance and body condition of a large, euryhaline fish. Mar Ecol Prog Ser 563:211-218

Brame AB, McIvor CC, Peebles EB, Hollander DJ (2014) Site fidelity and condition metrics suggest sequential habitat use by juvenile common snook. Mar Ecol Prog Ser 509: 255-269

* Brennan NP, Walters CJ, Leber KM (2008) Manipulations of stocking magnitude: addressing density-dependence in a juvenile cohort of common snook (Centropomus undecimalis). Rev Fish Sci 16:215-227

Burnham KP, Anderson DR (2002) Model selection and multi-model inference: a practical information-theoretic approach, $2^{\text {nd }}$ edn. Springer, New York, NY

Campana SE (1999) Chemistry and composition of fish otoliths: pathways, mechanisms and applications. Mar Ecol Prog Ser 188:263-297

Campana SE (2005) Otolith elemental composition as a natural marker of fish stocks. In: Cadrin SX, Friedland KD, Waldman JR (eds) Stock identification methods: applications in fishery science. Elsevier Academic Press, Burlington, MA, p 227-245

Chittaro PM, Finley RJ, Levin PS (2009) Spatial and temporal patterns in the contribution of fish from their nursery habitats. Oecologia 160:49-61

Clarke LM, Walther BD, Munch SB, Thorrold SR, Conover DO (2009) Chemical signatures in the otoliths of a coastal marine fish, Menidia menidia, from the northeastern United States: spatial and temporal differences. Mar Ecol Prog Ser 384:261-271

Connell SD, Gillanders BM (2007) Marine ecology. Oxford University Press, South Melbourne

* Dahlgren CP, Kellison GT, Adams AJ, Gillanders BM, Kendall MS, Layman CA, Ley JA and others (2006) Marine nurseries and effective juvenile habitats: concepts and applications. Mar Ecol Prog Ser 312:291-295

Day JW, Hall CAS, Kemp WM, Yanez-Arancibia A (1989) Estuarine ecology. John Wiley and Sons, New York, NY

* Deegan LA, Garritt RH (1997) Evidence for spatial variability in estuarine food webs. Mar Ecol Prog Ser 147:31-47

Elsdon TS, Wells BK, Campana SE, Gillanders BM, Jones CM, Limburg KE (2008) Otolith chemistry to describe movements and life-history parameters of fishes: hypotheses, assumptions, limitations, and inferences. Oceanogr Mar Biol Annu Rev 46:297-330

Enwright NM, Griffith KT, Osland MJ (2016) Barriers to and opportunities for landward migration of coastal wetlands with sea level rise. Front Ecol Environ 14:307-316

ESRI (Environmental Systems Research Institute) (2012) ArcGIS, release 10.1. ESRI, Redlands, CA

Fairclough DV, Edmonds JS, Lenanton RCJ, Jackson G, Keay IS, Crisafulli BM, Newman SJ (2011) Rapid and cost-effective assessment of connectivity among assemblages of Choerodon rubescens (Labridae), using laser ablation ICP-MS of sagittal otoliths. J Exp Mar Biol Ecol 403:46-53

Fairclough DV, Edmonds JS, Jackson G, Lenanton RCJ and others (2013) A comparison of the stock structures of two exploited demersal teleosts, employing complementary methods of otolith element analysis. J Exp Mar Biol Ecol 439:181-195

Fodrie FJ, Levin LA (2008) Linking juvenile habitat utilization to population dynamics of California halibut. Limnol Oceanogr 53:799-812

Fowler J, Cohen L, Jarvis P (1998) Practical statistics for field biology. John Wiley \& Sons, New York, NY

* Gerlach MJ, Engelhart SE, Kemp AC, Moyer RP, Smoak JM, Bernhardt CE, Cahill N (2017) Reconstructing Common Era relative sea-level change on the Gulf Coast of Florida. Mar Geol 390:254-269

*Gillanders BM (2005) Using elemental chemistry of fish otoliths to determine connectivity between estuarine and coastal habitats. Estuar Coast Shelf Sci 64:47-57

Gilmore RG, Donohoe CJ, Cooke DW (1983) Observations on the distribution and biology of east-central Florida populations of the common snook, Centropomus undecimalis (Bloch). Fla Sci 46:313-336

*Halpin PM (2000) Habitat use by an intertidal salt-marsh fish: trade-offs between predation and growth. Mar Ecol Prog Ser 198:203-214

Harrigan P, Zieman JC, Macko SA (1989) The base of nutritional support for the gray snapper (Lutjanus griseus): an evaluation based on a combined stomach content and stable isotope analysis. Bull Mar Sci 44:65-77

* Helsel DR (1990) Less than obvious - statistical treatment of data below the detection limit. Environ Sci Technol 24: 1766-1774

Helsel DR (2006) Fabricating data: how substituting values for nondetects can ruin results, and what can be done about it. Chemosphere 65:2434-2439

Jones D (2012) Processing LA-ICP-MS otolith microchemistry data using the Fathom Toolbox for Matlab. Technical Report 12.07.01, Laboratory for Otolith Microchemistry. College of Marine Science, University of South Florida, St. Petersburg, FL. www.marine.usf.edu/user/djones

* Jones DL, Walter JF, Brooks EN, Serafy JE (2010) Connectivity through ontogeny: fish population linkages among mangrove and coral reef habitats. Mar Ecol Prog Ser 401: 245-258

King M (2007) Fisheries biology, assessment, and management, $2^{\text {nd }}$ edn. Blackwell, Carleton

Ley JA (2014) Mangrove connectivity helps sustain coral reef fisheries under global climate change. In: Bortone SA (ed) Interrelationships between corals and fisheries. CRC Press, Boca Raton, FL, p 171-198

Ley JA, McIvor CC, Peebles EB, Rolls H (2010) Defining fish nursery habitats: an application of otolith elemental fingerprinting in Tampa Bay, Florida. In: Cooper ST (ed) Proc Tampa Bay Area Scientific Information Symp, BASIS 5. Tampa Bay Regional Planning Council, St. Petersburg, FL, p 331-346 
Litvin SY, Weinstein MP, Sheaves M, Nagelkerken I (2018) What makes nearshore habitats nurseries for nekton? An emerging view of the nursery role hypothesis. Estuaries Coasts 41:1539-1550

Longerich HP, Jackson SE, Gunther D (1996) Inter-laboratory note. Laser ablation inductively coupled plasma mass spectrometric transient signal data acquisition and analyte concentration calculation. J Anal At Spectrom 11:899-904

Malkin EM (2010) The economically important nitrogen pathways of southwest Florida. PhD dissertation, University of South Florida, St. Petersburg, FL

Mateo I, Durbin EG, Appeldoorn RS, Adams AJ and others (2010) Role of mangroves as nurseries for French grunt Haemulon flavolineatum and schoolmaster Lutjanus apodus assessed by otolith elemental fingerprints. Mar Ecol Prog Ser 402:197-212

McArdle BH, Anderson MJ (2001) Fitting multivariate models to community data: a comment on distance-based redundancy analysis. Ecology 82:290-297

McHugh JL (1967) Estuarine nekton. In: Lauff GH (ed) Estuaries. Am Assoc Adv Sci Spec Publ No. 83. AAAS, Washington, DC, p 581-619

McIvor CC, Odum WE (1988) Food, predation risk, and microhabitat selection in a marsh fish assemblage. Ecology 69:1341-1351

*McMichael RH Jr, Peters KM, Parsons GR (1989) Early life history of the snook, Centropomus undecimalis, in Tampa Bay, Florida. Northeast Gulf Sci 10:113-125

* Mercier L, Darnaude AM, Bruguier O, Vasconcelos RP and others (2011) Selecting statistical models and variable combinations for optimal classification using otolith microchemistry. Ecol Appl 21:1352-1364

Nagelkerken I (2009) Ecological connectivity among tropical coastal ecosystems. Springer-Verlag, New York, NY

Nagelkerken I, Dorenbosch M, Verberk W, Cocheret de la Moriniere E, van der Velde G (2000) Importance of shallow-water biotopes of a Caribbean bay for juvenile coral reef fishes: patterns in biotope association, community structure and spatial distribution. Mar Ecol Prog Ser 202: 175-192

Odum HT (1951) The stability of the world strontium cycle. Science 114:407-411

Olley R, Young RG, Closs GP, Kristensen EA and others (2011) Recruitment sources of brown trout identified by otolith trace element signatures. N Z J Mar Freshw Res 45:395-411

Patterson HM, Taylor RG, McBride RS (2005) Coastal origin of common snook, Centropomus undecimalis, in Florida Bay. Gulf Caribb Res 17:25-30

Peters KM, Matheson RE Jr, Taylor RG (1998) Reproduction and early life history of common snook, Centropomus undecimalis (Bloch), in Florida. Bull Mar Sci 62:509-529

Raabe EA, Stumpf RP (2016) Expansion of tidal marsh in response to sea-level rise: Gulf Coast of Florida, USA. Estuaries Coasts 39:145-157

Raabe EA, Roy LC, McIvor CC (2012) Tampa Bay coastal wetlands: nineteenth to twentieth century tidal marshto-mangrove conversion. Estuaries Coasts 35:1145-1162

Rakocinski CF, Comyns BH, Peterson MS, Shiller AM (2015) Regional patterns in the otolith chemistry of juvenile spotted seatrout (Cynoscion nebulosus) differ under contrasting hydrological regimes. Open Fish Sci J 8:1-12

Reis-Santos P, Gillanders BM, Tanner SE, Vasconcelos RP, Elsdon TS, Cabral HN (2012) Temporal variability in estuarine fish otolith elemental fingerprints: implications for connectivity assessments. Estuar Coast Shelf Sci 112: $216-224$

* Reis-Santos P, Tanner SE, Vasconcelos RP, Elsdon TS, Cabral HN, Gillanders BM (2013) Connectivity between estuarine and coastal fish populations: contributions of estuaries are not consistent over time. Mar Ecol Prog Ser 491:177-186

Reis-Santos P, Tanner SE, França S, Vasconcelos RP, Gillanders BM, Cabral HN (2015) Connectivity within estuaries: an otolith chemistry and muscle stable isotope approach. Ocean Coast Manage 118:51-59

Reis-Santos P, Vasconcelos RP, Tanner SE, Fonseca VF, Cabral HN, Gillanders BM (2018) Extrinsic and intrinsic factors shape the ability of using otolith chemistry to characterize estuarine environmental histories. Mar Environ Res 140:332-341

Rivas LR (1986) Systematic review of the perciform fishes of the genus Centropomus. Copeia 1986:579-611

* Roegner GC, Teel DJ (2014) Density and condition of subyearling Chinook salmon in the lower Columbia River and estuary in relation to water temperature and genetic stock of origin. Trans Am Fish Soc 143:1161-1176

Rolls HJ (2014) Using otolith elemental composition to track the habitat use, movements, and life history patterns of common snook (Centropomus undecimalis) and red drum (Sciaenops ocellatus) in the Tampa Bay estuary. $\mathrm{PhD}$ dissertation, University of South Florida, St. Petersburg, FL

Schilling HT, Reis-Santos P, Hughes JM, Smith JA and others (2018) Evaluating estuarine nursery use and life history patterns of Pomatomus saltatrix in eastern Australia. Mar Ecol Prog Ser 598:187-199

StatSoft (2008) Statistica. Microsoft Corporation, Tulsa, OK

Stevens PW, Blewett DA, Poulakis GR (2007) Variable habitat use by juvenile common snook, Centropomus undecimalis (Pisces: Centropomidae): applying a life-history model in a southwest Florida estuary. Bull Mar Sci 80: 93-108

* Stevens PW, Greenwood MF, Blewett DA (2013) Fish assemblages in the oligohaline stretch of a southwest Florida river during periods of extreme freshwater inflow variation. Trans Am Fish Soc 142:1644-1658

* Sturrock AM, Trueman CN, Darnaude AM, Hunter E (2012) Can otolith elemental chemistry retrospectively track migrations in fully marine fishes? J Fish Biol 81: 766-795

Tabachnick BG, Fidell LS (2013) Using multivariate statistics, $6^{\text {th }}$ edn. Pearson Education, Boston, MA

*Tanner SE, Reis-Santos P, Vasconcelos RP, Thorrold SR, Cabral HN (2013) Population connectivity of Solea solea and Solea senegalensis over time. J Sea Res 76:82-88

*Taylor RG, Grier HJ, Whittington JA (1998) Spawning rhythms of common snook in Florida. J Fish Biol 53: 502-520

Taylor RG, Whittington JA, Grier HJ, Crabtree RE (2000) Age, growth, maturation, and protandric sex reversal in common snook, Centropomus undecimalis, from the east and west coasts of South Florida. Fish Bull (Wash DC) 98: 612-624

Valiela I (1995) Marine ecological processes, 2nd edn. Springer-Verlag, New York, NY

*Valle-Levinson A, Dutton A, Martin JB (2017) Spatial and temporal variability of sea-level rise hotspots over the eastern United States. Geophys Res Lett 44:7876-7882 
Vasconcelos RP, Reis-Santos P, Costa MJ, Cabral HN (2011) Connectivity between estuaries and marine environment: integrating metrics to assess estuarine nursery function. Ecol Indic 11:1123-1133

Walther BD, Thorrold SR, Olney JE (2008) Geochemical signatures in otoliths record natal origins of American shad. Trans Am Fish Soc 137:57-69

Whitfield AK (2017) The role of seagrass meadows, mangrove forests, salt marshes and reed beds as nursery

Editorial responsibility: Stylianos Somarakis,

Heraklion, Greece areas and food sources for fishes in estuaries. Rev Fish Biol Fish 27:75-110

* Winner BL, Blewett DA, McMichael RH, Guenther CB (2010) Relative abundance and distribution of common snook along shoreline habitats of Florida estuaries. Trans Am Fish Soc 139:62-79

* Young JM, Yeiser BG, Whittington JA (2014) Spatiotemporal dynamics of spawning aggregations of common snook on the east coast of Florida. Mar Ecol Prog Ser 505:227-240

Submitted: May 13, 2018; Accepted: September 27, 2018

Proofs received from author(s): November 10, 2018 